\title{
1,1,3,3-Tetrakis(alkylthio)-1,3-dilithio-2-silapropanes: useful reagents for the synthesis of polysilacycloalkanes via dianionic ring formation
}

\section{Masaki Shimizu, ${ }^{a, *}$ Masayuki Iwakubo, ${ }^{b}$ Yasushi Nishihara, ${ }^{b, \#}$ Katsunari Oda, ${ }^{a}$ and Tamejiro Hiyama ${ }^{a}$}

\author{
${ }^{a}$ Research Laboratory of Resources Utilization, Tokyo Institute of Technology, 4259 Nagatsuta, \\ Midori-ku, Yokohama, Kanagawa 226-8503, Japan. ${ }^{b}$ Department of Material Chemistry, \\ Graduate School of Engineering, Kyoto University, Katsura Campus, Nishikyo-ku, Kyoto 615- \\ 8510, Japan \\ \# Present address: Department of Chemistry, Okayama University, 3-1-1 Tsushimanaka, \\ Okayama, 700-8530, Japan \\ Email:shimizu@npc05.kuic.kyoto-u.ac.jp
}

This manuscript is dedicated to Professor Alain Krief's 65th birthday and retirement

\begin{abstract}
Treatment of 1,1,3,3-tetrakis(alkylthio)-2-silapropanes with $t$-BuLi in $\mathrm{THF}$ at $-40{ }^{\circ} \mathrm{C}$ generated 1,1,3,3-tetrakis(alkylthio)-1,3-dilithio-2-silapropanes which reacted with various bifunctional chlorosilanes to give the corresponding 4- to 7-membered polysilacycloalkanes in moderate to good yields. Furthermore, double alkylation of the dilithiated silanes with bis(halomethyl)diorganosilanes or dihaloalkanes was found to proceed smoothly giving rise to 1,4-disilacyclohexanes or silacycloalkanes in good yields, respectively, in THF and an aprotic polar co-solvent such as hexamethylphosphoric triamide (HMPA) or 1,1,3,3-tetramethylurea (TMU). The sulfenyl groups in the cyclized products were smoothly removed by radical reduction with tributyltin hydride.
\end{abstract}

Keywords: Dianion, lithium, polysilacycloalkane, silicon

\section{Introduction}

Growing interest has been paid on polysilacycloalkanes, cycloalkanes containing one or more silicon atoms in the ring, as target molecules or precursors of polymers, ceramics, and functional materials as well as in the hypervalent silicon chemistry. For example, 1,3-disilacyclobutanes are converted into polycarbosilanes by ring-opening polymerization, ${ }^{1}$ and silacyclohexanes are 
shown to behave as a mesogen of liquid crystals, ${ }^{2}$ while 1,1,3,3,5,5-hexafluoro-1,3,5trisilacyclohexane ${ }^{3}$ and 1,1,4,4-tetrafluoro-1,4-disilacyclohexane ${ }^{4}$ are demonstrated to capture a fluoride ion. Therefore, there have been needs of general synthetic methods for polysilacycloalkanes, applicable to a variety of ring sizes and substitution patterns of silicon atoms. ${ }^{5}$ We have envisaged that the ring-closure reaction of 1,3-dimetallo-2-silapropanes 1 with bis(electrophile) 2 should be a powerful strategy for the preparation of polysilacycloalkanes 3 (equation 1$)^{6}$

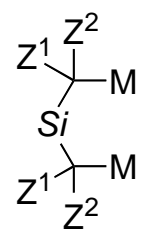

1

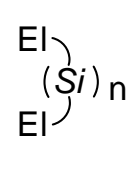

2

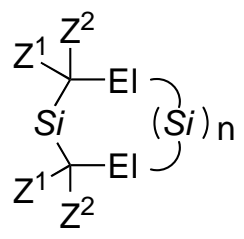

3

Due probably to their instability, however, 1,3-dimetallo-2-silapropanes $\mathbf{1}$ are rarely used in organic synthesis in contrast with (triorganosilyl)methylmetal reagents. There a few precedents of 1,3-dilithio-2-silapropanes that are classified into bis(lithiomethyl)diorganosilanes (1: $Z^{1}, Z^{2}=$ $\mathrm{H})^{7}$ and bis(lithiophenylmethyl) dimethylsilane $\left(\mathbf{1}: \mathrm{Z}^{1}=\mathrm{H}, \mathrm{Z}^{2}=\mathrm{Ph}\right){ }^{8}$ Those dianionic reagents were prepared by chlorine-lithium exchange of the parent silanes with lithium, or reductive cleavage of $\mathrm{C}-\mathrm{S}$ bonds with lithium or lithium naphthalenide (Scheme 1), and allowed to react with an electrophile such as chlorotrimethylsilane and tributylchlorostannane to give the corresponding acyclic products in moderate to good yields, whereas ring construction of 1,3dilithio-2-silapropanes was limited to the synthesis of such 4-membered rings as 1,3disilacyclobutanes, 1-germa-3-silacyclobutane, and 1-titana-3-silacyclobutane, and yields of the cyclized products were usually low to moderate at best.


Scheme 1. Examples of 1,3-disilacyclobutane formation from 1,3-dilithio-2-silapropanes. 
In connection with our research on the synthesis of 1,3-disilacyclohexanes using bis(alkylthio)(chloromethyldimethylsilyl)methane, ${ }^{9}$ we became interested in preparation and reactions of 1,1,3,3-tetrakis(alkylthio)-1,3-dilithio-2-silapropanes $\left(\mathbf{1}, \mathrm{Z}^{1}, \mathrm{Z}^{2}=\mathrm{SR}\right){ }^{10}$ What we envisaged was that two sulfenyl groups at both 1-, and 3-positions would facilitate the generation of the dianion from the parent 2-silapropanes, stabilize the dianion, ${ }^{11}$ and allow us to achieve the ring formation effectively, and in addition, are readily introduced and removed. ${ }^{12}$ We report here facile synthesis of polysilacycloalkanes via the reactions of $\mathbf{1}\left(Z^{1}, Z^{2}=S R\right)$ with bis(chlorosilane)s or bis(alkyl halide)s. ${ }^{13}$

\section{Results and Discussion}

\section{Preparation of bis[bis(alkylthio)methyl]diorganosilanes and bis(halomethyl) diorganosilanes}

Bis[bis(alkylthio)methyl]diorganosilanes (5) were prepared by silylation of bis(alkylthio)methyllithium, generated from commercially available bis(methylthio)methane or 1,3-dithiane with BuLi, with dichlorodiorganosilanes $\mathrm{R}^{1} \mathrm{R}^{2} \mathrm{SiCl}_{2}$ as shown in Scheme 2.

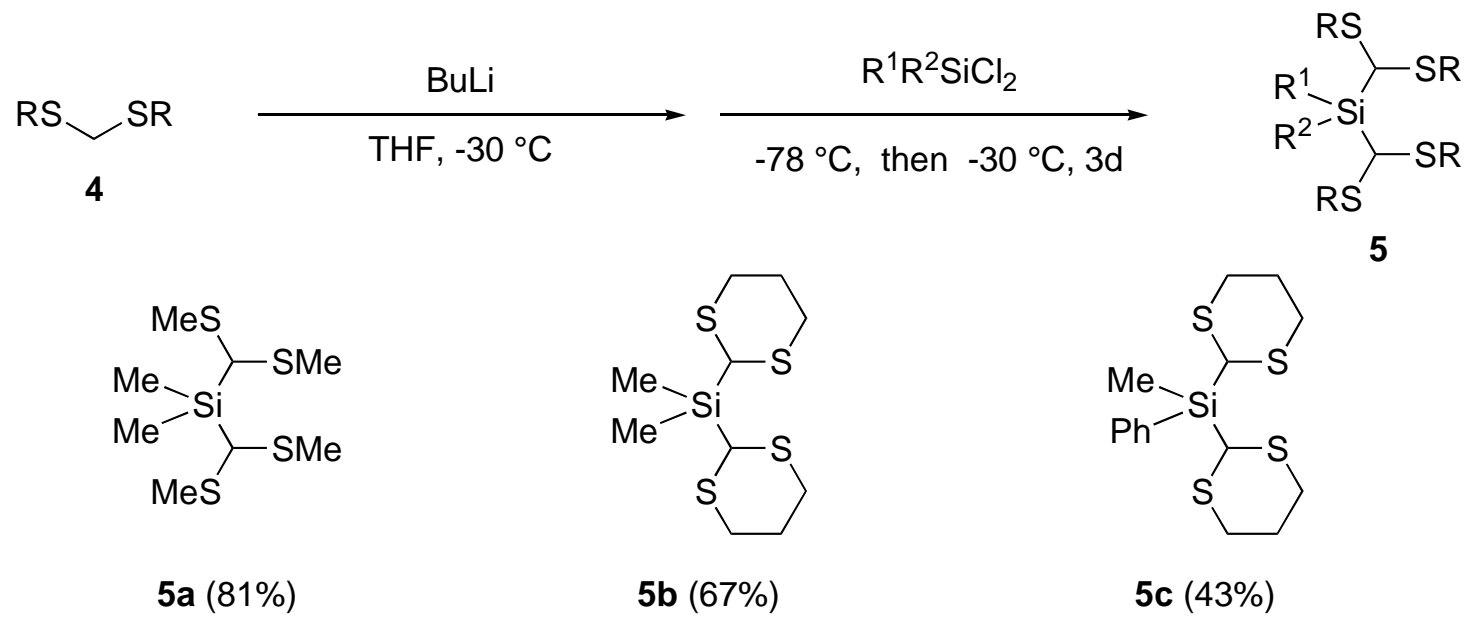

Scheme 2. Preparation of 5.

Preparation of bis(halomethyl)silanes $\mathbf{6}$ is summarized in Scheme 3. Bis(chloromethyl)diphenylsilane (6a) was synthesized by silylation of chloromethyllithium, generated in situ from chloroiodomethane and MeLi, with dichlorodiphenylsilane. Halogen exchange of 6a, bis(chloromethyl)methylphenylsilane, and bis(chloromethyl)dimethylsilane with $\mathrm{LiBr}$ or $\mathrm{NaI}$ gave the corresponding bis(bromomethyl) or -(iodomethyl) derivatives (6b-e, and 6f), repectively. Bis(mesylate) 6d was prepared from 6a via substitution of chlorine atoms with acetoxy groups followed by reduction with $\mathrm{LiAlH}_{4}$ and subsequent mesylation with $\mathrm{MsCl}$. 

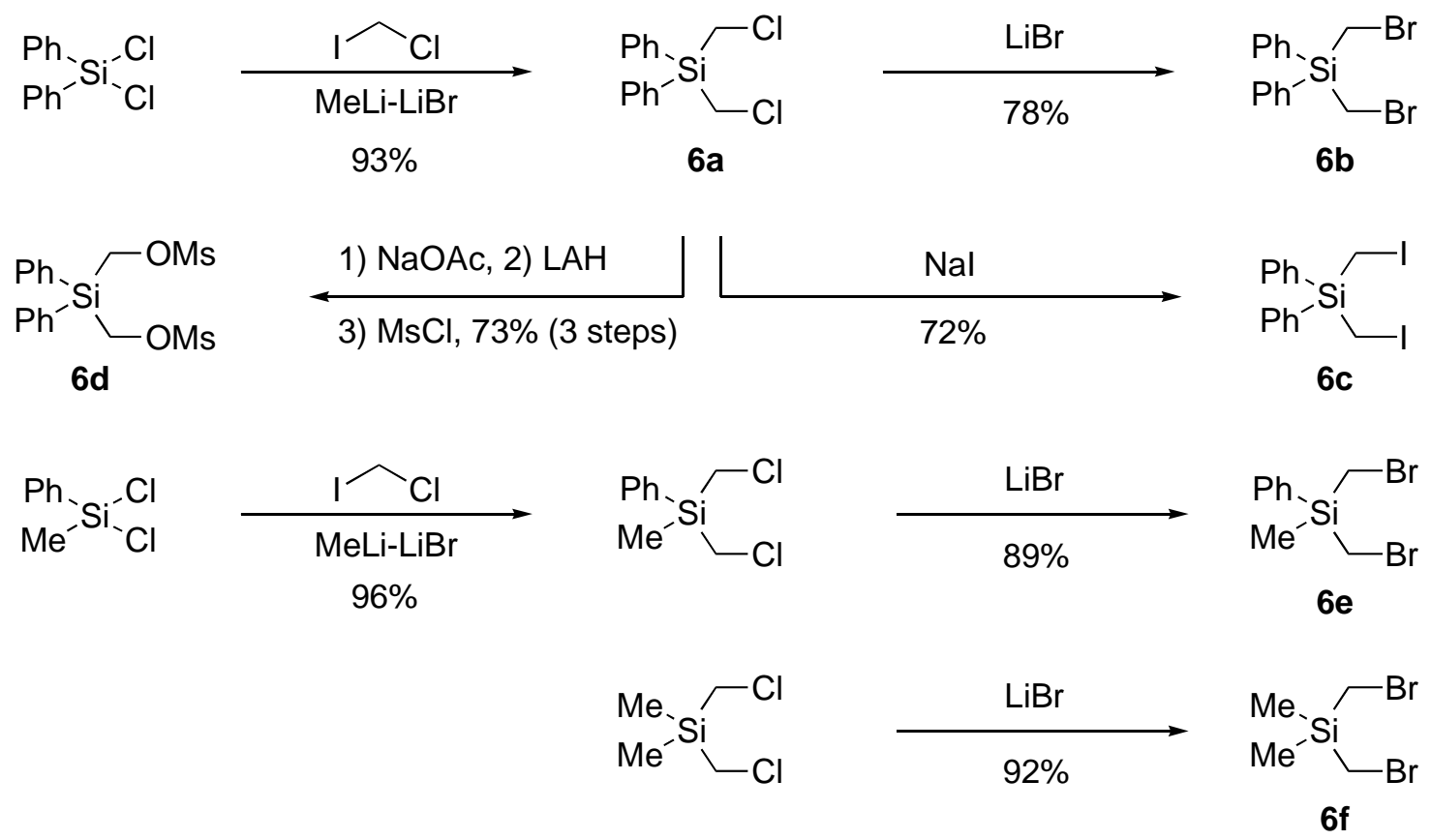

Scheme 3. Preparation of bis(halomethyl)silanes 6.

\section{Generation and disilylation of bis[bis(methylthio)lithiomethyl]dimethylsilane}

First of all, the synthesis of various-sized polysilacycloalkanes was studied by disilylation of bis[bis(methylthio)lithiomethyl]dimethylsilane (1a) with bifunctional chlorosilanes 2 (Scheme 4).

Lithiation of 5a (1 molar amount) with $t$-BuLi (2.2 molar amounts) in THF at $-40{ }^{\circ} \mathrm{C}$ followed by reaction with bifunctional chlorosilanes 2 (1.1 molar amounts) in THF at $-78{ }^{\circ} \mathrm{C}$ to room temperature gave cyclized product 7 . The results are summarized in Scheme 4 and Table 1. With dichlorodiorganosilanes 2a-c, four-membered silanes $\mathbf{7 a - c}$ were produced in moderate to good yields, respectively (entries 1-3). The yields are generally higher than those obtained from the reaction of 2a with bis(lithiomethyl)dimethylsilane (24\%) or bis(lithiomethyl)diphenylsilane $(46 \%)$ (see, Scheme 1), and thus it is apparent that the sulfenyl groups in 1,3-dianion 1a are the key to the success of the dianionic ring formation. Silylation of 1a with 1,2-dichlorodisilane 2d successfully gave 1,3,4-trisilacyclopentane 7d (entry 4). Six-membered rings 7e-g were also prepared in a similar way (entries 5-7). Silicon-silicon and silicon-oxygen bonds were found to tolerate the basic conditions. The introduction of dimethylsilylene, methylene, or oxygen into the 4-position of 1,3,5-trisilacyclohexane derivatives could be effected simply by changing the bis(electrophile) employed. Low yield of $\mathbf{7 g}$ may be attributed to longer bond lengths of both silicon-silicon and silicon-carbon bonds than a carbon-carbon bond making an enthaplic factor closer to 7-membered ring formation rather than 6-membered carbocycle formation. Similarly, 7membered trisilacycle $\mathbf{7 h}$ was produced by silylation with $\mathbf{2 h}$ in a relatively low yield (entry 8 ). 


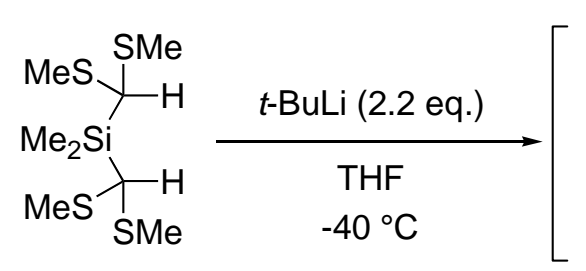

$5 a$

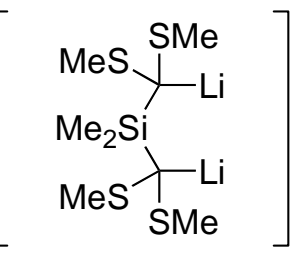

1a

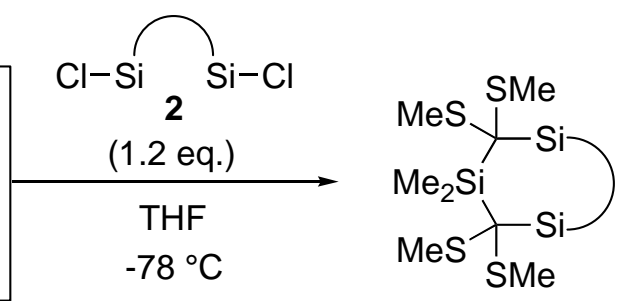

7

\section{Scheme 4}

Table 1. Synthesis of polysilacycloalkanes 7 via double silylation of 1 a with 2 .

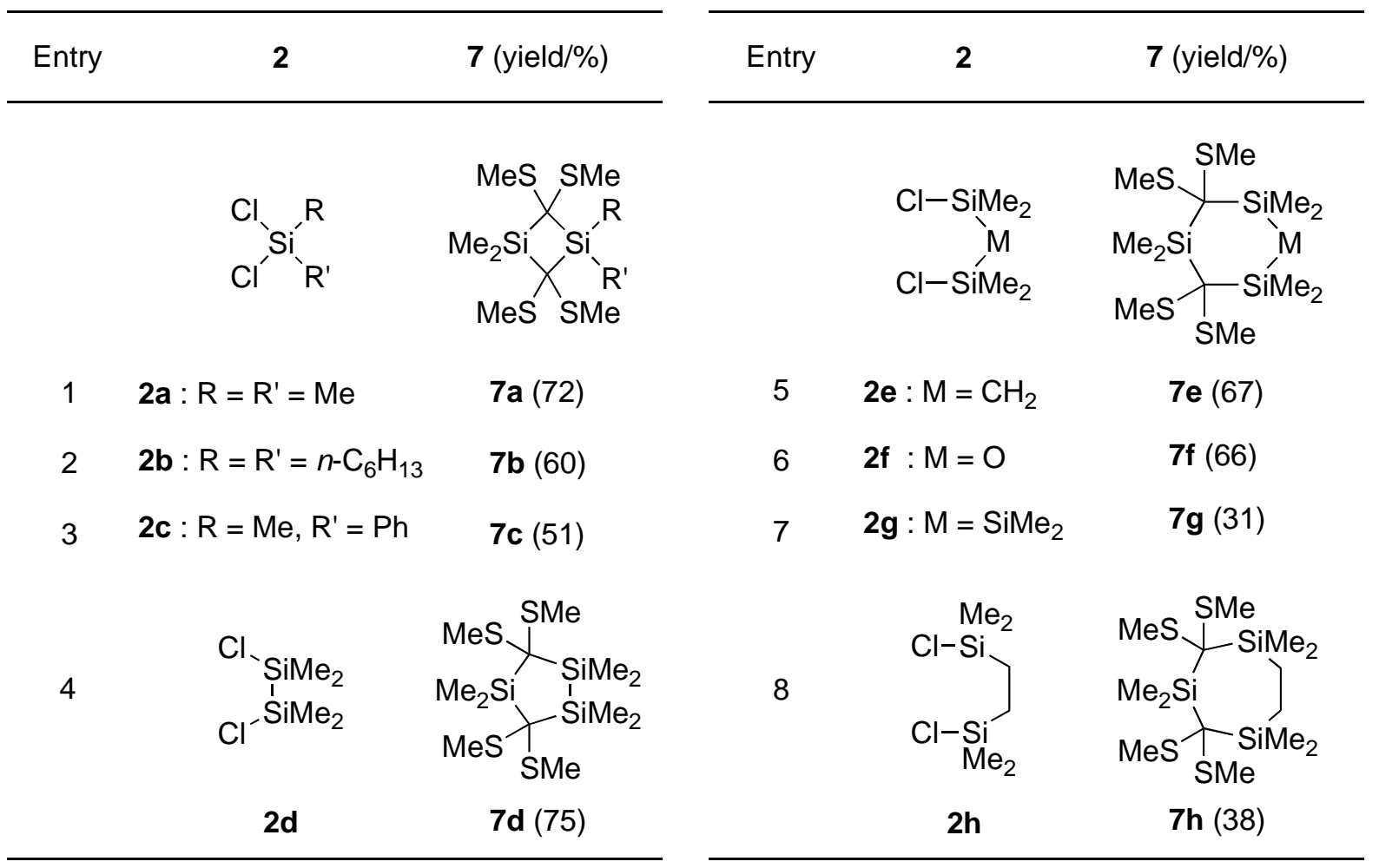

Double alkylation of 1b and 1c: synthesis of 1,4-disilacyclohexanes and silacyclohexanes Successful double silylation of the sulfur-stabilized 1,1,3,3-tetrakis(methylthio)-1,3-dilithio-2silapropanes (1a) led us to study alkylation to further extend the synthetic utility of 1a, because electrophiles used in the reactions of 1,3-dilithio-2-silapropanes were limited to such reactive ones as chlorosilanes and chlorogermanes. Alkylation of those dilithiated reagents has, to the best of our knowledge, no precedents.

For an alkylation reagent, we first used a bis(halomethyl)silane which seems to be relatively reactive due to the silicon accelerating effect. ${ }^{14}$

When 1a was treated with bis(bromomethyl)diphenylsilane (6b) in THF or THF/HMPA, alkylation did not take place and 1a was recovered unchanged. As $\mathbf{6 b}$ was consumed completely 
to give unidentified products, the 1,3-dianion 1a appears to have behaved as a base to cause deprotonation at the bromine-attached carbons. In view that 2-lithio-2-triorganosilyl-1,3dithianes undergo alkylation, ${ }^{15}$ we reexamined the alkylation with bis[1,3-dithian-2-yl]silane $\mathbf{1 b}$, and the results are summarized in Scheme 5 and Table 2. Although no alkylation took place in THF only, $\mathbf{6 b}$ was recovered quantitatively in sharp contrast with $\mathbf{1 a}$ (entry 1). ${ }^{16}$ In view that 2 lithio-2-silyl-1,3-dithiane can be usually alkylated in THF, ${ }^{15}$ the result of entry 1 shows that the reactivity of $\mathbf{1 b}$ is lower than that of 2-lithio-2-silyl-1,3-dithiane. To our delight, addition of such an aprotic polar co-solvent as 1,3-dimethylpropyleneurea (DMPU), 1,1,3,3-tetramethylurea (TMU), and hexamethylphosphoric triamide (HMPA) was effective to afford 1,4disilacyclohexane 8a (entries 2-4). Judging from the fact that the addition of an electron donor solvent often enhances the carbanionic character of alkyllithiums by decreasing aggregation degree, ${ }^{17}$ the success of alkylation may be attributed to some structural change of $\mathbf{1 b}$. As for an alkylating reagent $\mathbf{6}$, bromine turned out to be the best leaving group among the tested ones (entries 4-7). To our surprise, bis(iodomethyl)silane 6c gave no desired product, although iodine is the better leaving group than bromine usually. Using the solvent system consisting of THF and TMU, and bis(bromomethyl)silanes as an alkylating reagent, 1,4-disilacyclohexanes 8b-f having various substituents on silicon were prepared as colorless plates (entries 8-12). These are the first examples of the alkylation of 1,3-dilithio-2-silapropanes.



$5 b$ or $5 c$

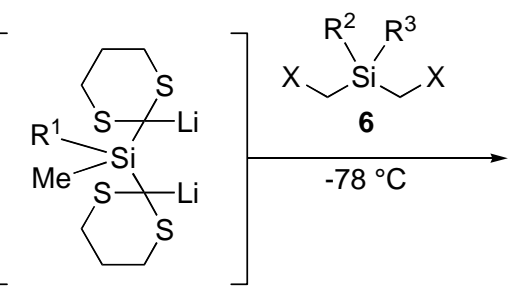

1b or 1c

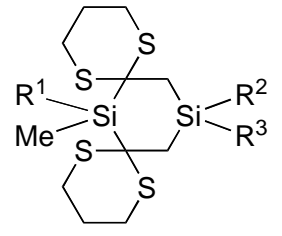

8

\section{Scheme 5}

Table 2. Synthesis of 1,4-disilacyclohexanes 8 via double alkylation of $\mathbf{1 b}$ or $\mathbf{1 c}$ with $\mathbf{6}$

\begin{tabular}{cccccccccc}
\hline Entry & $\mathbf{5}$ & $\mathrm{R}^{1}$ & Co-solvent & $\mathbf{6}$ & $\mathrm{R}^{2}$ & $\mathrm{R}^{3}$ & $\mathrm{X}$ & $\mathbf{8}$ & Yield/\% \\
\hline 1 & $\mathbf{5 b}$ & $\mathrm{Me}$ & none & $\mathbf{6 b}$ & $\mathrm{Ph}$ & $\mathrm{Ph}$ & $\mathrm{Br}$ & $\mathbf{8 a}$ & 0 \\
2 & $\mathbf{5 b}$ & $\mathrm{Me}$ & $\mathrm{DMPU}$ & $\mathbf{6 b}$ & $\mathrm{Ph}$ & $\mathrm{Ph}$ & $\mathrm{Br}$ & $\mathbf{8 a}$ & 34 \\
3 & $\mathbf{5 b}$ & $\mathrm{Me}$ & $\mathrm{TMU}$ & $\mathbf{6 b}$ & $\mathrm{Ph}$ & $\mathrm{Ph}$ & $\mathrm{Br}$ & $\mathbf{8 a}$ & 69 \\
4 & $\mathbf{5 b}$ & $\mathrm{Me}$ & $\mathrm{HMPA}$ & $\mathbf{6 b}$ & $\mathrm{Ph}$ & $\mathrm{Ph}$ & $\mathrm{Br}$ & $\mathbf{8 a}$ & 52 \\
5 & $\mathbf{5 b}$ & $\mathrm{Me}$ & $\mathrm{HMPA}$ & $\mathbf{6 a}$ & $\mathrm{Ph}$ & $\mathrm{Ph}$ & $\mathrm{Cl}$ & $\mathbf{8 a}$ & 20 \\
6 & $\mathbf{5 b}$ & $\mathrm{Me}$ & $\mathrm{HMPA}$ & $\mathbf{6 c}$ & $\mathrm{Ph}$ & $\mathrm{Ph}$ & $\mathrm{I}$ & $\mathbf{8 a}$ & 0 \\
7 & $\mathbf{5 b}$ & $\mathrm{Me}$ & $\mathrm{HMPA}$ & $\mathbf{6 d}$ & $\mathrm{Ph}$ & $\mathrm{Ph}$ & $\mathrm{OMs}$ & $\mathbf{8 a}$ & 0 \\
8 & $\mathbf{5 b}$ & $\mathrm{Me}$ & $\mathrm{TMU}$ & $\mathbf{6 e}$ & $\mathrm{Ph}$ & $\mathrm{Me}$ & $\mathrm{Br}$ & $\mathbf{8 b}$ & 76 \\
9 & $\mathbf{5 b}$ & $\mathrm{Me}$ & $\mathrm{TMU}$ & $\mathbf{6 f}$ & $\mathrm{Me}$ & $\mathrm{Me}$ & $\mathrm{Br}$ & $\mathbf{8 c}$ & 68 \\
10 & $\mathbf{5 c}$ & $\mathrm{Ph}$ & $\mathrm{TMU}$ & $\mathbf{6 b}$ & $\mathrm{Ph}$ & $\mathrm{Ph}$ & $\mathrm{Br}$ & $\mathbf{8 d}$ & 48 \\
11 & $\mathbf{5 c}$ & $\mathrm{Ph}$ & $\mathrm{TMU}$ & $\mathbf{6 e}$ & $\mathrm{Ph}$ & $\mathrm{Me}$ & $\mathrm{Br}$ & $\mathbf{8 e}$ & 42 \\
12 & $\mathbf{5 c}$ & $\mathrm{Ph}$ & $\mathrm{TMU}$ & $\mathbf{6 f}$ & $\mathrm{Me}$ & $\mathrm{Me}$ & $\mathrm{Br}$ & $\mathbf{8 f}$ & 70 \\
\hline
\end{tabular}


The alkylation methodology is applicable to the synthesis of different types of silacycloalkanes only by choosing different bifunctional electrophiles (Scheme 6). Silacyclopentane 10a was obtained with 1,2-dibromoethane in a low yield, whereas alkylation of 1b with 1,3-dibromopropane gave silacyclohexane 10b in an acceptable yield. Methylene, cyclohexylidene, and hydroxyl group-substituted silacyclohexanes 10c-e also produced in fair yields. Moreover, with 1,2-bis(bromomethyl)benzene, silacycloheptane 10f was successfully synthesized in $67 \%$ yield probably thanks to the geometrical constraint at the bromomethyl groups.

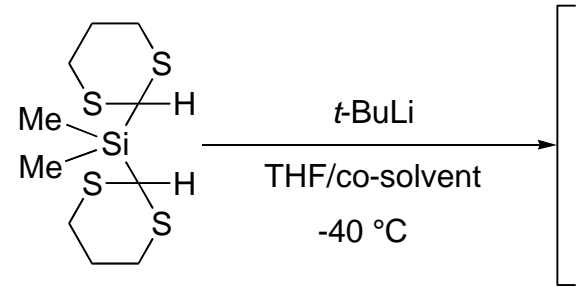

$5 b$

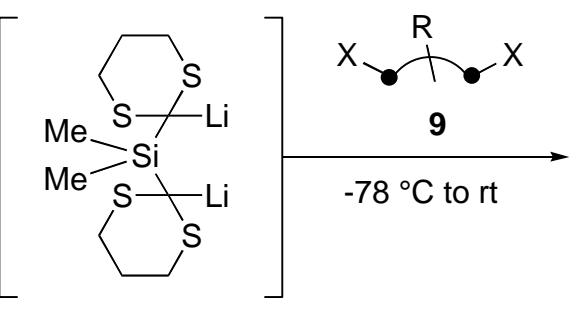

1b

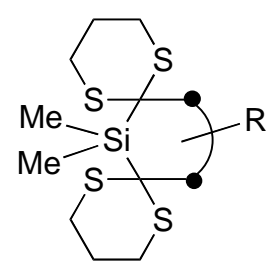

10

\section{Scheme 6}

Table 3. Synthesis of silacycloalkanes 10

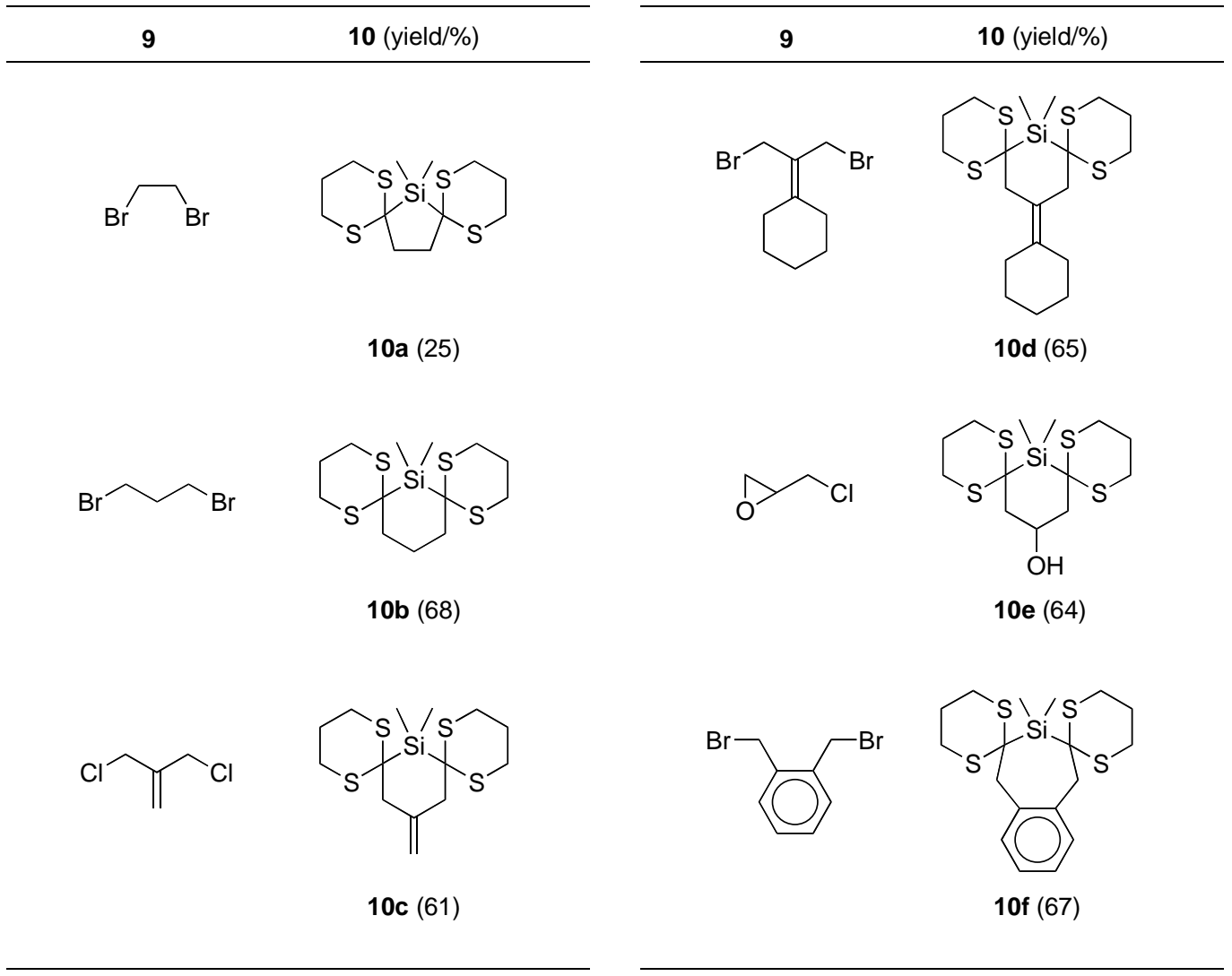




\section{Molecular structure of 1,3-dithianyl-substituted 1,4-disilacyclohexane}

The molecular structure of $\mathbf{8 a}$ is shown in Figure $1 .{ }^{18}$ Two 1,3-dithianyl rings adopted strain-free chair conformation, whereas 1,4-disilacyclohexane ring takes a twist-boat conformation with silicon-carbon bond lengths of $\mathrm{Si}(2)-\mathrm{C}(2)$ and $\mathrm{Si}(2)-\mathrm{C}(4)$ being $1.929(2)$ and 1.926(2) $\AA$, respectively, somewhat longer than the normal silicon-carbon bond length $(1.89 \AA) .{ }^{19}$ Another characteristic feature is the arrangement of $\mathrm{S}(2), \mathrm{Si}(2)$, and $\mathrm{S}(4)$ atoms. To our surprise, these three atoms are aligned almost linearly $\left(\mathrm{S}(2)-\mathrm{Si}(2)-\mathrm{S}(4)=174.7^{\circ}\right)$ and the atomic distances of $\mathrm{Si}(2)-\mathrm{S}(2)$ and $\mathrm{Si}(2)-\mathrm{S}(4)$, being 3.002 and $2.963 \AA$, respectively, are longer than the $\mathrm{Si}-\mathrm{S}$ bond of $\mathrm{H}_{3} \mathrm{SiSH}(2.14 \AA)^{20}$ but shorter than the sum of the van der Waals radii of Si $(2.10 \AA)$ and sulfur $(1.80 \AA) .{ }^{21}$ The twist form may be attributable to the steric repulsion between the C(4)$\mathrm{S}(3)$ and the $\mathrm{C}(2)-\mathrm{S}(2)$ bonds, but the interaction between the silicon and two sulfur atoms should be considered also. ${ }^{22}$

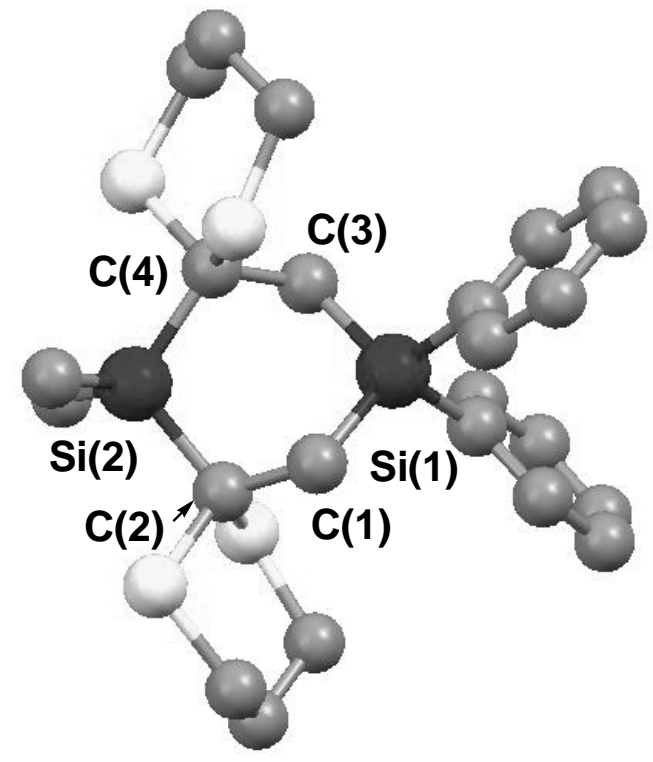

(a)

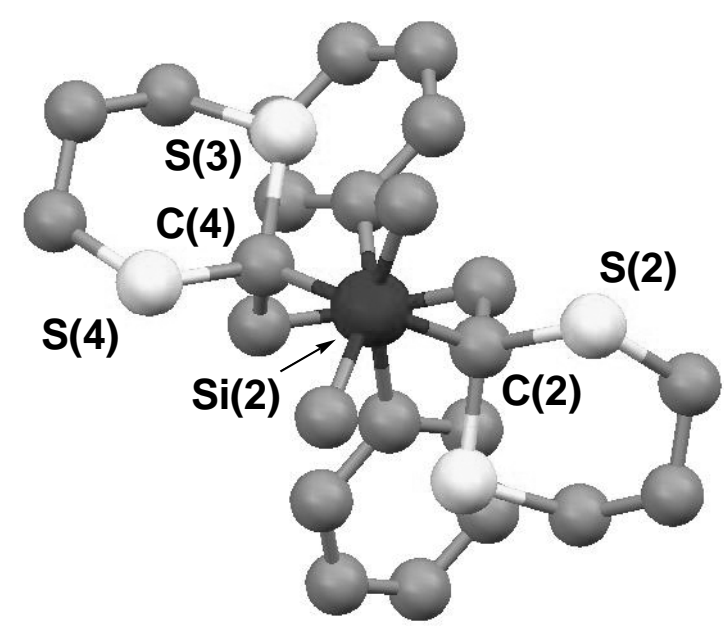

(b)

Figure 1. Molecular structure of 8a (Silicon: black; Sulfur: white; Carbon: gray).

\section{Removal of the sulfenyl groups in polysilacycloalkanes}

Desulfurization of the cyclized products was finally examined. Attempted reduction of 7e with Raney Ni (W2) or Benkeser reduction (lithium/primary amine) failed, whereas radicalic reduction with hydrosilane or -stannane in the presence of AIBN was found effective as summarized in Equation 2. In particular, $\mathrm{Bu}_{3} \mathrm{SnH}$ reduced $7 \mathbf{e}$ much faster than hydrosilane to give 11 in a yield (NMR) comparable to the silane reduction. To demonstrate generality of the stannane reduction, the conditions were applied to 7c, 7d, 7e, 8a, and $\mathbf{8 e}$, cleanly producing $\mathbf{1 2 -}$ 15, respectively, as summarized in Scheme 7. 


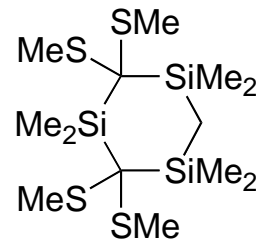

$7 e$

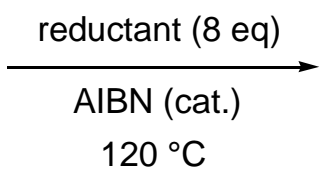

$120^{\circ} \mathrm{C}$

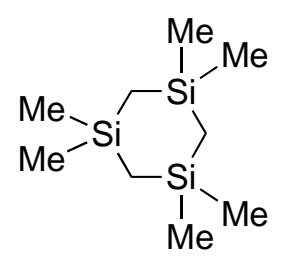

(2)

Table 4. Reduction of 7e

\begin{tabular}{ccc}
\hline Reductant & Time (h) & Yield (\%) $^{\mathrm{a}}$ \\
\hline$\left(\mathrm{Me}_{3} \mathrm{Si}\right)_{3} \mathrm{SiH}$ & 10 & 98 \\
$(i-\mathrm{PrS})_{3} \mathrm{SiH}$ & 10 & 91 \\
$\mathrm{Bu}_{3} \mathrm{SnH}$ & 3 & 88 \\
$\mathrm{Ph}_{3} \mathrm{SnH}$ & 3 & 54 \\
\hline
\end{tabular}

a Yield was determined by ${ }^{1} \mathrm{H}$ NMR anaylsis of the crude product using trichloroethylene as an internal standard.

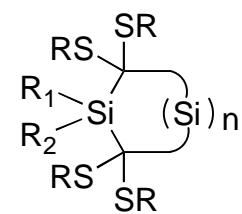

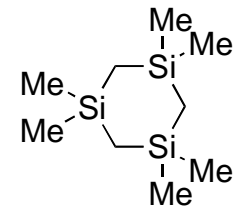

11

(64\% yield)



12

(48\% yield)
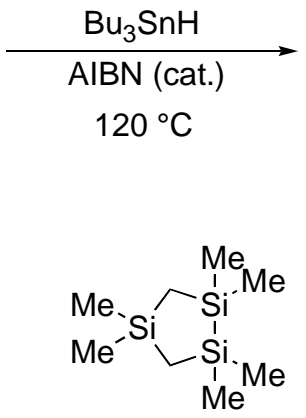

13 (58\% yield)

11

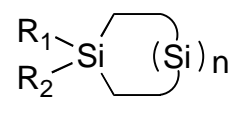

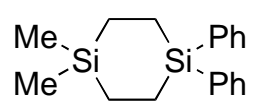

14

(54\% yield)

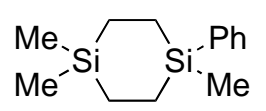

15

(74\% yield)

Scheme 7. Removal of the sulfenyl groups in $\mathbf{7}$ and $\mathbf{8}$.

In summary, we have shown that 1,1,3,3-tetrakis(alkylthio)-1,3-dilithio-2-silapropanes are a novel class of dianionic reagent and successfully undergo double silylation and alkylation leading to tetrakis(alkylthio)-substituted polysilacycloalkanes. The sulfenyl groups can be easily removed with $\mathrm{Bu}_{3} \mathrm{SnH}$. This protocol definitely allows to prepare a diverse range of polysilacycloalkanes that will find applications in silicon-containing materials. 


\section{Experimental Section}

General Procedures. Melting points were determined using a Yanagimoto Micro Melting Point Apparatus and were not corrected. ${ }^{1} \mathrm{H}$ NMR spectra were measured on a Varian Mercury 200 (200 MHz), $300(300 \mathrm{MHz})$, or $400(400 \mathrm{MHz})$ spectrometer. The chemical shifts of ${ }^{1} \mathrm{H} \mathrm{NMR}$ are expressed in parts per million downfield relative to the internal tetramethylsilane $(\delta=0 \mathrm{ppm})$ or chloroform $(\delta=7.26 \mathrm{ppm})$. Splitting patterns are indicated as s, singlet; d, doublet; t, triplet; q, quartet; brs, broad singlet. ${ }^{13} \mathrm{C}$ NMR spectra were measured on a Varian Mercury 400 (100 $\mathrm{MHz})$, or JEOL EX-270 (67.8 MHz) spectrometer with tetramethylsilane $(\delta=0 \mathrm{ppm})$ or chloroform- $d(\delta=77.0 \mathrm{ppm})$ as an internal standard. ${ }^{29} \mathrm{Si}$ NMR spectra were measured on a Varian Mercury $300(59.6 \mathrm{MHz})$ spectrometer with tetramethylsilane as an internal standard $(\delta=$ $0 \mathrm{ppm}$ ). Chemical shifts are given in parts per million downfield relative to the internal standard. Infrared spectra (IR) were recorded on a Shimadzu FTIR-8400 spectrometer. GC-MS analyses were performed with a JEOL JMS-700 spectrometer by electron ionization at $70 \mathrm{eV}$ unless otherwise indicated. Elemental analyses were carried out with a YANAKO MT2 CHN CORDER machine at Elemental Analysis Centers of Kyoto University or Tokyo Institute of Technology. TLC analyses were performed by means of Merck Kieselgel $60 \mathrm{~F}_{254}$; column chromatography was carried out using Merck Kieselgel 60 (230-400 mesh). All reactions were carried out under an argon atmosphere. Tetrahydrofuran, diethyl ether, and hexane were distilled from sodium benzophenone ketyl right before use. HMPA, DMPU and TMU were purchased from Tokyo Kasei Organic Chemicals or Aldrich Chemical Co. Inc. and distilled from $\mathrm{CaH}_{2}$ and stored over MS4A.

Bis[bis(methylthio)methyl]dimethylsilane (5a). A hexane solution of butyllithium (1.48 M, 14 $\mathrm{mL}, 21 \mathrm{mmol}$ ) was added to a solution of bis(methylthio)methane $(2.1 \mathrm{~mL}, 21 \mathrm{mmol})$ in THF (20 $\mathrm{mL}$ ) at $-30{ }^{\circ} \mathrm{C}$, and the resulting solution was stirred at $-30{ }^{\circ} \mathrm{C}$ for $2 \mathrm{~h}$. To the solution was added dichlorodimethylsilane $(1.25 \mathrm{~mL}, 10 \mathrm{mmol})$ at $-78{ }^{\circ} \mathrm{C}$, and the solution was stirred at $-30{ }^{\circ} \mathrm{C}$ for $48 \mathrm{~h}$ before quenching with sat. aq. $\mathrm{NH}_{4} \mathrm{Cl}$ at $-30{ }^{\circ} \mathrm{C}$. The aqueous layer was extracted with a mixture of ethyl acetate and dichloromethane. The combined organic layer was dried over anhydrous magnesium sulfate and concentrated in vacuo. The residue was purified by silica gel column chromatography (hexane/dichloromethane $4: 1)$ to give $5 \mathbf{a}(2.2 \mathrm{~g})$ as a colorless oil in $81 \%$ yield. ${ }^{1} \mathrm{H}$ NMR $\delta 0.30(\mathrm{~s}, 6 \mathrm{H}), 2.20(\mathrm{~s}, 12 \mathrm{H}), 3.27$ (s, 2H); ${ }^{13} \mathrm{C}$ NMR $\delta$-3.9, 15.3, 39.5; IR (neat) 2973, 2915, 2361, 1435, 1422, 1250, 1088, 961, 847, 828, $785 \mathrm{~cm}^{-1}$; MS/EI m/z $272\left(\mathrm{M}^{+}\right.$, 0.9), 225 (20), 137 (77), 120 (19), 109 (34), 107 (100), 105 (50), 91 (26), 75 (28), 61 (20); HRMS (EI): Calcd for $\mathrm{C}_{8} \mathrm{H}_{20} \mathrm{~S}_{4} \mathrm{Si}\left(\mathrm{M}^{+}\right)$272.0217. Found 272.0198.

Bis[1,3-dithian-2-yl]dimethylsilane (5b). Colorless plates; mp $134{ }^{\circ} \mathrm{C}$ (hexane); ${ }^{1} \mathrm{H}$ NMR $\delta$ $0.29(\mathrm{~s}, 6 \mathrm{H}), 1.89-2.21(\mathrm{~m}, 4 \mathrm{H}), 2.72(\mathrm{dt}, J=3.7,13.5 \mathrm{~Hz}, 4 \mathrm{H}), 2.91$ (ddd, $J=2.9,11.7,14.1 \mathrm{~Hz}$, 4H), 3.94 (s, 2H); ${ }^{13} \mathrm{C}$ NMR $\delta-6.5,26.1,31.1,31.4 ;{ }^{29} \mathrm{Si}$ NMR $\delta 4.5$; IR (KBr) 3903, 1418, 1293 , 1271, 1248, 1157, 1094, 1001, 909, 878, 830, 812, 783, 729, $669 \mathrm{~cm}^{-1}$; MS/EI m/z $296\left(\mathrm{M}^{+}, 5\right)$, 177 (7), 149 (31), 132 (17), 119 (100), 115 (12), 100 (8), 91 (11), 75 (18), 73 (14); Anal. Calcd 
for $\mathrm{C}_{10} \mathrm{H}_{20} \mathrm{~S}_{4} \mathrm{Si}: \mathrm{C}, 40.50 ; \mathrm{H}, 6.80 ; \mathrm{S}, 43.24 \%$. Found: C, 40.22; H, 6.70; $\mathrm{S}, 43.48 \%$.

Bis[1,3-dithian-2-yl]methylphenylsilane (5c). Colorless plates; mp 119-120 ${ }^{\circ} \mathrm{C}$ (hexane); ${ }^{1} \mathrm{H}$ NMR $\delta 0.64(\mathrm{~s}, 3 \mathrm{H}), 1.80-2.22(\mathrm{~m}, 4 \mathrm{H}), 2.55-3.08(\mathrm{~m}, 8 \mathrm{H}), 4.21(\mathrm{~s}, 2 \mathrm{H}), 7.27-7.50(\mathrm{~m}, 3 \mathrm{H})$, 7.62-7.70 (m, 2H); ${ }^{13} \mathrm{C}$ NMR $\delta$-8.1, 25.9, 31.0, 31.2, 31.3, 127.7, 130.2, 130.5, 135.1; IR (KBr) 2944, 2899, 1420, 1267, 1254, 1238, 1150, 1092, 999, 907, 876, 822, 760, 723, 700, 673, 598, $480 \mathrm{~cm}^{-1}$; MS/EI m/z $358\left(\mathrm{M}^{+}, 11\right), 239$ (22), 211 (18), 179 (10), 177 (8), 149 (8), 132 (44), 121 (47), 119 (100), 105 (76), 91 (25), 75 (36); Anal. Calcd for $\mathrm{C}_{15} \mathrm{H}_{22} \mathrm{~S}_{4} \mathrm{Si}$ : C, 50.23; H, 6.18; S, 35.75\%. Found: C, 49.97; H, 6.04; S, 36.42\%.

Bis(chloromethyl)diphenylsilane (6a). To a solution of dichlorodiphenylsilane $(2.1 \mathrm{~mL}, 10$ mmol) and chloroiodomethane $(2.2 \mathrm{~mL}, 30 \mathrm{mmol})$ in THF $(40 \mathrm{~mL})$ was added a solution of MeLi-LiBr complex $(1.5 \mathrm{M}$ in ether, $20 \mathrm{~mL}, 30 \mathrm{mmol})$ dropwise at $-78^{\circ} \mathrm{C}$. The reaction mixture was allowed to warm to room temperature before quenching with sat. aq. $\mathrm{NH}_{4} \mathrm{Cl}$. The aqueous layer was extracted with hexane. The combined organic layer was dried over anhydrous magnesium sulfate and concentrated in vacuo. The residue was purified by silica gel column chromatography (hexane) to give $6 a(2.6 \mathrm{~g})$ as a colorless oil in 93\% yield. ${ }^{1} \mathrm{H}$ NMR $\delta 3.43$ (s, 4H), 7.32-7.70 (m, 10H); ${ }^{13} \mathrm{C}$ NMR $\delta 25.9,128.2(2 \mathrm{C}), 130.7,135.2 ;{ }^{29} \mathrm{Si}$ NMR $\delta 12.6$; IR (neat) 3071, 2930, 2359, 1960, 1887, 1821, 1590, 1489, 1428, 1387, 1115, 999, 761, 739, $698 \mathrm{~cm}^{-1}$; MS/EI m/z $282\left(\mathrm{M}^{+}+2,0.9\right), 280\left(\mathrm{M}^{+}, 1\right), 233$ (38), 231 (100), 195 (23), 167 (19), 153 (19), 105 (10), 91 (48); HRMS (EI) Calcd for $\mathrm{C}_{14} \mathrm{H}_{14} \mathrm{Cl}_{2} \mathrm{Si}\left(\mathrm{M}^{+}\right)$280.0242. Found 280.0232.

Bis(bromomethyl)diphenylsilane (6b). A mixture of 6a $(3.4 \mathrm{~g}, 12 \mathrm{mmol}), \mathrm{LiBr}(2.6 \mathrm{~g}, 30$ $\mathrm{mmol})$ and Aliquat $336(0.28 \mathrm{~mL}, 0.6 \mathrm{mmol})$ was heated at $100{ }^{\circ} \mathrm{C}$ for $12 \mathrm{~h}$. Workup followed by silica gel column chromatography (hexane) gave $6 \mathbf{b}(3.5 \mathrm{~g})$ as a colorless oil in $78 \%$ yield. ${ }^{1} \mathrm{H}$ NMR $\delta 3.10$ (s, 4H), 7.35-7.70 (m, 10H); ${ }^{13} \mathrm{C}$ NMR $\delta 12.1,128.3,130.7,131.1,135.3 ;{ }^{29} \mathrm{Si}$ NMR $\delta$-12.5; IR (neat) 3071, 3050, 2938, 2361, 1958, 1885, 1819, 1590, 1487, 1428, 1383, 1192, 1117, 997, 772, 723, $696 \mathrm{~cm}^{-1}$; MS/EI m/z $372\left(\mathrm{M}^{+}+4,0.6\right), 370\left(\mathrm{M}^{+}+2,2\right), 368\left(\mathrm{M}^{+}, 0.7\right), 323$ (29), 277 (98), 275 (98), 195 (76), 181 (20), 167 (39), 105 (56), 91 (100), 65 (41); HRMS (EI) Calcd for $\mathrm{C}_{14} \mathrm{H}_{14} \mathrm{Br}_{2} \mathrm{Si}\left(\mathrm{M}^{+}\right)$367.9233. Found 367.9233 .

Bis(iodomethyl)diphenylsilane (6c). A mixture of 6a (1.4 g, $5 \mathrm{mmol})$, NaI (2.7 g, $18 \mathrm{mmol})$ in acetone $(5 \mathrm{~mL})$ was stirred in the dark at room temperature for $48 \mathrm{~h}$. The remaining NaI was removed by filtration and the filtrate was concentrated in vacuo. The residue was purified by silica gel column chromatography (hexane) to give $6 \mathrm{c}(1.65 \mathrm{~g})$ as a colorless oil in $72 \%$ yield. ${ }^{1} \mathrm{H}$ NMR $\delta 2.65(\mathrm{~s}, 4 \mathrm{H}), 7.30-7.69(\mathrm{~m}, 10 \mathrm{H}) ;{ }^{13} \mathrm{C}$ NMR $\delta-18.1,128.1,130.5,131.9,135.2$; IR (neat) 3069, 3048, 2932, 1955, 1880, 1819, 1590, 1428, 1370, 1192, 1117, 997, 733, 714, $696 \mathrm{~cm}^{-1}$; MS/EI m/z 464 (M+, 7), 337 (68), 323 (100), 209 (16), 195 (38), 181 (15), 167 (15), 155 (10), 131 (14), 105 (40), 91 (37), 69 (24); HRMS (EI) Calcd for $\mathrm{C}_{14} \mathrm{H}_{14} \mathrm{I}_{2} \mathrm{Si}\left(\mathrm{M}^{+}\right)$463.8958. Found 463.8947.

Bis(methanesulfonylmethyl)diphenylsilane (6d). A solution of 6a (4.9 g, 18 mmol), sodium acetate (3.6 g, $44 \mathrm{mmol})$ and tetrabutylammonium iodide $(0.65 \mathrm{mg}, 1.8 \mathrm{mmol})$ in tetrachloromethane $(35 \mathrm{~mL})$ was heated to reflux for $144 \mathrm{~h}$. The resulting mixture was treated with sat. aq. $\mathrm{NaHCO}_{3}$ and the aqueous layer was extracted with ethyl acetate. The combined 
organic layer was dried over anhydrous magnesium sulfate and concentrated in vacuo. The mixture was passed through a short pad of silica gel (hexane/ethyl acetate $4: 1$ ). Crude bis(acetoxymethyl)-diphenylsilane was used for the next transformation without further purification. ${ }^{1} \mathrm{H}$ NMR $\delta 2.00(\mathrm{~s}, 6 \mathrm{H}), 4.37$ (s, 4H), 7.38-7.65 (m, 10H); ${ }^{13} \mathrm{C}$ NMR $\delta$ 20.7, 53.3, 128.2, 130.4, 135.1, 171.5; IR (KBr) 3069, 3029, 2938, 295, 2110, 1975, 1919, 1898, 1732, 1429, 1370, 1292, 1225, 1117, 130, 889, 793, 741, 702, 610, 475, $459 \mathrm{~cm}^{-1}$. To a solution of $\mathrm{LiAlH}_{4}$ $(0.91 \mathrm{~g}, \quad 24 \mathrm{mmol})$ in diethyl ether $(30 \mathrm{~mL})$ was added a solution of bis(acetoxymethyl)diphenylsilane $(3.94 \mathrm{~g}, 12 \mathrm{mmol})$ in diethyl ether $(12 \mathrm{~mL})$ at $0{ }^{\circ} \mathrm{C}$. The reaction mixture was heated to reflux for $24 \mathrm{~h}$ before quenching with water $(0.85 \mathrm{~mL})$ and $3 \mathrm{M}$ $\mathrm{NaOH}$ aq. $(2.6 \mathrm{~mL})$. The resulting precipitates were removed by filtration, and the filtrate was concentrated in vacuo. The residue was passed through a short pad of silica gel (hexane/ethyl acetate $1: 1$ ) to give bis(hydroxymethyl)diphenylsilane. ${ }^{1} \mathrm{H}$ NMR $\delta 2.14$ (brs, 2H), 4.09 (s, 4H), 7.30-7.72 (m, 10H); ${ }^{13} \mathrm{C}$ NMR $\delta 53.5,128.2,130.1,135.1$; IR (KBr) 3250, 2909, 1962, 1883, $1833,1588,1428,1267,1202,1117,997,985,787,733,700,484,457 \mathrm{~cm}^{-1}$. To a mixture of the crude bis(hydroxymethyl)diphenylsilane $(0.24 \mathrm{~g}, 1.0 \mathrm{mmol})$ and triethylamine $(0.35 \mathrm{~mL}, 2.5$ mmol) in THF $(2 \mathrm{~mL})$ was added methanesulfonyl chloride $(0.18 \mathrm{~mL}, 2.3 \mathrm{mmol})$ at $0{ }^{\circ} \mathrm{C}$. The reaction mixture was stirred at $0{ }^{\circ} \mathrm{C}$ for $30 \mathrm{~min}$ before quenching with $1 \mathrm{M} \mathrm{HCl}$ solution. The aqueous layer was extracted with ethyl acetate, and the combined organic layer was dried over anhydrous magnesium sulfate and concentrated in vacuo. The residue was purified by silica gel column chromatography (hexane/ethyl acetate $1: 1)$ to give $\mathbf{6 d}(360 \mathrm{mg}$ ) as a colorless oil in $96 \%$ yield. ${ }^{1} \mathrm{H}$ NMR $\delta 2.96(\mathrm{~s}, 6 \mathrm{H}), 4.49(\mathrm{~s}, 4 \mathrm{H}), 7.37-7.65(\mathrm{~m}, 10 \mathrm{H}) ;{ }^{13} \mathrm{C}$ NMR $\delta 36.2,57.6$, 128.0, 128.5, 131.2, 135.2; IR (neat) 3029, 2940, 1732, 1429, 1356, 1283, 1175, 1121, 976, 962, 836, 810, 735, $700 \mathrm{~cm}^{-1}$. Anal. Calcd for $\mathrm{C}_{15} \mathrm{H}_{17} \mathrm{O}_{3} \mathrm{SSS}$ : C, 58.98; H, 5.61; S, 10.50\%. Found: $\mathrm{C}$, $59.00 ; \mathrm{H}, 5.55 ; \mathrm{S}, 10.75 \%$.

Bis(bromomethyl)methylphenylsilane (6e). A colorless oil; ${ }^{1} \mathrm{H}$ NMR $\delta 0.60$ (s, 3H), 2.77 (d, $J$ $=13.1 \mathrm{~Hz}, 2 \mathrm{H}), 2.86(\mathrm{~d}, J=13.1 \mathrm{~Hz}, 2 \mathrm{H}), 7.30-7.68(\mathrm{~m}, 5 \mathrm{H}) ;{ }^{13} \mathrm{C} \mathrm{NMR} \delta-6.1,13.5,128.2(2 \mathrm{C})$, 130.4, 134.1; IR (neat) 3071, 3050, 2936, 1956, 1881, 1817, 1592, 1428, 1385, 1256, 1117, 816, 83, 768, $698 \mathrm{~cm}^{-1}$; MS/EI m/z $310\left(\mathrm{M}^{+}+4,0.6\right), 308\left(\mathrm{M}^{+}+2,0.9\right), 306\left(\mathrm{M}^{+}, 0.7\right), 261(74), 215$ (51), 213 (52), 187 (16), 185 (16), 133 (90), 119 (21), 105 (39), 91 (100); HRMS (EI) Calcd for $\mathrm{C}_{9} \mathrm{H}_{12} \mathrm{Br}_{2} \mathrm{Si}\left(\mathrm{M}^{+}\right)$305.9076. Found 305.9065.

Bis(bromomethyl)dimethylsilane (6f). A colorless oil, bp $128{ }^{\circ} \mathrm{C} / 103$ torr. ${ }^{1} \mathrm{H}$ NMR: 0.29 (s, 6H), 2.58 (s, 4H); ${ }^{13} \mathrm{C}$ NMR: -4.7, 14.9; IR (neat): 2961, 2936, 2901, 2853, 1385, 1254, 1132, 1057, 845, 816, 795, 768, 737, $702 \mathrm{~cm}^{-1}$; Anal. Calcd for $\mathrm{C}_{4} \mathrm{H}_{10} \mathrm{Br}_{2} \mathrm{Si}: \mathrm{C}, 19.53 ; \mathrm{H}, 4.10$. Found: C, 19.81; H, 4.01.

A typical procedure for generation and silylation of 1a. Preparation of 1,1,3,3-tetramethyl2,2,4,4-tetrakis(methylthio)-1,3-disilacyclobutane (7a). To a solution of 5a $(0.27 \mathrm{~g}, 1.00$ mmol) in THF $(2 \mathrm{~mL})$ was added a solution of $t$-BuLi $(1.51 \mathrm{M}$ in pentane, $1.46 \mathrm{~mL}, 2.2 \mathrm{mmol})$ at $-40{ }^{\circ} \mathrm{C}$. The solution was stirred at $-40{ }^{\circ} \mathrm{C}$ for $3 \mathrm{~h}$ before treatment with a solution of dichlorodimethylsilane $(2 \mathrm{a}, 0.15 \mathrm{~mL}, 1.3 \mathrm{mmol})$ in THF $(1.3 \mathrm{~mL})$ at $-78{ }^{\circ} \mathrm{C}$. The resulting solution was allowed to warm to room temperature over a period of $2 \mathrm{~h}$ and quenched with 
saturated $\mathrm{NH}_{4} \mathrm{Cl}$ aqueous solution. The aqueous layer was extracted with a mixture of ethyl acetate and dichloromethane (3 times). The combined organic layer was dried over anhydrous magnesium sulfate and concentrated in vacuo. The residue was purified by silica gel column chromatography (hexane/dichloromethane $4: 1)$ to give $7 \mathbf{a}(0.23 \mathrm{~g}, 72 \%$ yield) as colorless plates. Mp 114-116 ${ }^{\circ} \mathrm{C}$ (hexane/dichloromethane); ${ }^{1} \mathrm{H}$ NMR $\delta 0.52(\mathrm{~s}, 12 \mathrm{H}), 2.00(\mathrm{~s}, 12 \mathrm{H}) ;{ }^{13} \mathrm{C} \mathrm{NMR} \delta$ 1.3, 13.5, 33.7; ${ }^{29} \mathrm{Si}$ NMR $\delta$ 15.2; IR (KBr) 2916, 1417, 1394, 1300, 1259, 1252, 1246, 972, 947 , 870, 835, 810, 785, 752, 733, 709, cm ${ }^{-1}$; MS/EI m/z $328\left(\mathrm{M}^{+}, 0.9\right), 313$ (8), 283 (22), 282 (23), 281 (100), 223 (7), 207 (13), 195 (21), 161 (38), 149 (10), 137 (24), 129 (50), 105 (86), 73 (21); HRMS (EI): Calcd for $\mathrm{C}_{10} \mathrm{H}_{24} \mathrm{~S}_{4} \mathrm{Si}_{2}\left(\mathrm{M}^{+}\right)$328.0299. Found 328.0314.

1,1-Dihexyl-3,3-dimethyl-2,2,4,4-tetrakis(methylthio)-1,3-disilacyclobutane (7b). Colorless oil; ${ }^{1} \mathrm{H}$ NMR $\delta 0.55(\mathrm{~s}, 6 \mathrm{H}), 0.82-0.98(\mathrm{~m}, 6 \mathrm{H}), 1.02-1.16(\mathrm{~m}, 4 \mathrm{H}), 1.22-1.48(\mathrm{~m}, 16 \mathrm{H}), 2.01(\mathrm{~s}$, $12 \mathrm{H}) ;{ }^{13} \mathrm{C}$ NMR $\delta-5.73,7.98,9.09,9.57,18.1,18.8,26.8,28.8,19.3 ;{ }^{29} \mathrm{Si} \mathrm{NMR} \delta 14.7,15.2$; IR (neat) 2957, 2924, 2855, 2363, 1480, 1246, 1180, 1099, 965, 857, 835, $737 \mathrm{~cm}^{-1}$; MS/EI m/z 468 $\left(\mathrm{M}^{+}, 0.4\right), 421$ (25), 362 (9), 245 (35), 161 (100), 137 (15), 123 (24), 113 (25), 105 (39), 91 (18), 85 (30), 77 (35); HRMS (EI): Calcd for $\mathrm{C}_{20} \mathrm{H}_{44} \mathrm{~S}_{4} \mathrm{Si}_{2}\left(\mathrm{M}^{+}\right)$468.1864. Found 468.1869.

1,1,3-Trimethyl-2,2,4,4-tetrakis(methylthio)-3-phenyl-1,3-disilacyclobutane (7c). Colorless plates; mp 118-119 ${ }^{\circ} \mathrm{C}$ (hexane/dichloromethane); ${ }^{1} \mathrm{H}$ NMR $\delta 0.65$ (s, 6H), 0.88 (s, 3H), 1.76 (s, $6 \mathrm{H}), 1.99$ (s, 6H), 7.34-7.50 (m, 3H), 8.02-8.14 (m, 2H); ${ }^{29} \mathrm{Si}$ NMR $\delta$-1.3, 16.5; IR (KBr) 3052, 2911, 1428, 1308, 1250, 1103, 967, 857, 810, 789, 737, $698 \mathrm{~cm}^{-1}$; MS/EI m/z $390\left(\mathrm{M}^{+}, 0.9\right), 343$ (62), 284 (16), 221 (26), 2009 (14), 191 (56), 167 (100), 137 (29), 135 (25), 121 (24), 105 (61), 91 (23); HRMS (EI): Calcd for $\mathrm{C}_{15} \mathrm{H}_{26} \mathrm{~S}_{4} \mathrm{Si}_{2}\left(\mathrm{M}^{+}\right)$390.0456. Found 390.0453.

1,1,2,2,4,4-Hexamethyl-3,3,5,5-tetrakis(methylthio)-1,2,4-trisilacyclopentane (7d). Colorless plates; mp 166-167 ${ }^{\circ} \mathrm{C}$ (hexane/dichloromethane); ${ }^{1} \mathrm{H}$ NMR $\delta 0.35$ (s, 12H), $0.39(\mathrm{~s}, 6 \mathrm{H}), 2.08$ (s, $12 \mathrm{H}) ;{ }^{13} \mathrm{C}$ NMR $\delta-1.9,0.7,12.7,31.4 ;{ }^{29} \mathrm{Si}$ NMR $\delta$-7.3, 16.8; IR (KBr) 2974, 2949, 2912, 1435, 1415, 1300, 1252, 1244, 972, 941, 831, 821, 792, 765, 735, $692 \mathrm{~cm}^{-1}$; MS/EI m/z $386\left(\mathrm{M}^{+}, 0.9\right)$, 373 (15), 372 (17), 371 (57), 219 (21), 195 (30), 175 (14), 137 (25), 129 (25), 105 (100), 73 (83); HRMS (EI): Calcd for $\mathrm{C}_{12} \mathrm{H}_{30} \mathrm{~S}_{4} \mathrm{Si}_{3}\left(\mathrm{M}^{+}\right)$386.0538. Found 386.0518.

1,1,3,3,5,5-Hexamethyl-2,2,4,4-tetrakis(methylthio)-1,3,5-trisilacyclohexane (7e). Colorless plates; mp 64-66 ${ }^{\circ} \mathrm{C}$ (hexane/dichloromethane); ${ }^{1} \mathrm{H}$ NMR $\delta 0.15$ (s, 2H), $0.29(\mathrm{~s}, 12 \mathrm{H}), 0.46$ (s, 6H), 2.09 (s, 12H); ${ }^{13} \mathrm{C}$ NMR $\delta 1.4,2.2,2.7,12.6,32.5 ;{ }^{29} \mathrm{Si}$ NMR $\delta 6.7,10.6$; IR (KBr) 2976, 2955, 2914, 1437, 1421, 1346, 1304, 1252, 1049, 970, 945, 837, 802, 754, $686 \mathrm{~cm}^{-1}$; MS/EI m/z $400\left(\mathrm{M}^{+}, 3\right), 296$ (24), 295 (30), 294 (100), 281 (17), 280 (20), 279 (82), 231 (19), 221 (18), 201 (14), 189 (16), 177 (81), 159 (23), 147 (31), 105 (61), 73 (48); HRMS (EI): Calcd for $\mathrm{C}_{13} \mathrm{H}_{32} \mathrm{~S}_{4} \mathrm{Si}_{3}\left(\mathrm{M}^{+}\right)$400.0695. Found 400.0669.

2,2,4,4,6,6-Hexamethyl-3,3,5,5-tetrakis(methylthio)-1-oxa-2,4,6-trisilacyclohexane(7f). Colorless plates; mp $88{ }^{\circ} \mathrm{C}$ (hexane/dichloromethane); ${ }^{1} \mathrm{H}$ NMR $\delta 0.38$ (s, 12H), 0.45 (s, 6H), 2.07 (s, 12H); ${ }^{13} \mathrm{C}$ NMR $\delta-3.7,-2.1,7.8,29.7 ;{ }^{29} \mathrm{Si}$ NMR $\delta 10.2,11.6$; IR (KBr) 2959, 2913, 1435, 1252, 1038, 974, 841, 808, 695, $567 \mathrm{~cm}^{-1}$; MS/EI m/z $(30 \mathrm{eV}) 405\left(\mathrm{M}^{+}+2,26\right), 404\left(\mathrm{M}^{+}+1\right.$, 26), 403 (M+ $\mathrm{M}^{+}$), 299 (85), 298 (99), 297 (91), 282 (100), 234 (33), 224 (30), 204 (24), 180 (54), 106 (24); HRMS (EI): Calcd for $\mathrm{C}_{12} \mathrm{H}_{30} \mathrm{OS}_{4} \mathrm{Si}_{3}\left(\mathrm{M}^{+}\right)$402.0487. Found 402.0499. 
1,1,2,2,4,4,6,6-Octamethyl-3,3,5,5-tetrakis(methylthio)-1,2,4,6-tetrasilacyclohexane

(7g). Colorless plates; mp $175{ }^{\circ} \mathrm{C}$ (hexane/dichloromethane); ${ }^{1} \mathrm{H}$ NMR $\delta 0.29(\mathrm{~s}, 6 \mathrm{H}), 0.35(\mathrm{~s}, 12 \mathrm{H})$, 0.49 (s, 6H), $2.09(12 \mathrm{H}) ;{ }^{13} \mathrm{C}$ NMR $\delta-4.9,-0.2,1.7,12.9,34.5 ;{ }^{29} \mathrm{Si}$ NMR $\delta$-47.1, -6.7, 13.1; IR (KBr) 2973, 2913, 1401, 1304, 1252, 1238, 963, 835, 820. 803, 733, 691, $654 \mathrm{~cm}^{-1}$; MS/EI m/z $429\left(\mathrm{M}^{+}, 16\right), 323$ (13), 265 (6), 233 (37), 105 (51), 73 (100). Anal. Calcd for $\mathrm{C}_{14} \mathrm{H}_{36} \mathrm{~S}_{4} \mathrm{Si}_{4}: \mathrm{C}$, 37.79 ; H, 8.15; S, 28.82\%. Found: C, 37.50; H, 8.35; S, 28.09\%.

1,1,3,3,5,5-Hexamethyl-2,2,4,4-tetrakis(methylthio)-1,3,5-trisilacycloheptane (7h). Colorless plates; mp 82-83 ${ }^{\circ} \mathrm{C}$ (hexane/dichloromethane); ${ }^{1} \mathrm{H}$ NMR $\delta 0.27$ (s, 12H), 0.45 (s, 6H), 0.93 (s, 4H), 2.13 (s, 12H); ${ }^{13} \mathrm{C}$ NMR $\delta 0.7,1.2,9.3,13.2,33.7 ;{ }^{29} \mathrm{Si}$ NMR $\delta 10.3,10.8$; IR (KBr) 2976, 2955, 2910, 2870, 1415, 1300, 1259, 1252, 1242, 1099, 1014, 974, 949, 831, 789, $758 \mathrm{~cm}^{-1}$; MS/EI m/z 414 (M+, 7), 310 (13), 309 (19), 308 (52), 293 (15), 261 (6), 247 (6), 223 (13), 203 (25), 191 (29), 173 (22), 161 (23), 149 (67), 105 (100), 74 (90), 73 (69); HRMS (EI): Calcd for $\mathrm{C}_{14} \mathrm{H}_{34} \mathrm{~S}_{4} \mathrm{Si}_{3}\left(\mathrm{M}^{+}\right)$414.0851. Found 414.0856.

A typical procedure for double alkylation of $5 \mathrm{~b}$ or $5 \mathrm{c}$ with dihaloalkanes: preparation of 1,5,9,13-Tetrathio-7,15-disila-7,7-dimethyl-15,15-diphenyltrispiro[5,1,5,3]hexadecane (8a)

To a stirred solution of bis[1,3-dithian-2-yl]-dimethylsilane $(\mathbf{1 b}, 0.30 \mathrm{~g}, 1.0 \mathrm{mmol})$ in THF (2 $\mathrm{mL})$ and TMU $(0.48 \mathrm{~mL}, 4.0 \mathrm{mmol})$ was added a solution of $t$ - BuLi $(1.51 \mathrm{M}$ in pentane, $1.46 \mathrm{~mL}$, $2.2 \mathrm{mmol}$ ) at $-40{ }^{\circ} \mathrm{C}$. The reaction mixture was stirred for $3 \mathrm{~h}$ and then cooled to $-78{ }^{\circ} \mathrm{C}$. To the reaction mixture was added a solution of bis(bromomethyl)diphenylsilane $(6 \mathbf{b}, 0.48 \mathrm{~g}, 1.3 \mathrm{mmol})$ in THF $(1.3 \mathrm{~mL})$. The resulting mixture was gradually warmed to room temperature over a period of $2 \mathrm{~h}$ and quenched with sat. aq. $\mathrm{NH}_{4} \mathrm{Cl}$. The aqueous layer was extracted with a mixture of ethyl acetate and dichloromethane. The combined organic layer was dried over anhydrous magnesium sulfate and concentrated in vacuo. The residue was purified by silica gel column chromatography (hexane/dichloromethane $1: 1)$ to give $8 \mathbf{a}(350 \mathrm{mg}$ ) in $69 \%$ yield. Colorless plates; mp 210-212 ${ }^{\circ} \mathrm{C}$ (hexane/dichloromethane); ${ }^{1} \mathrm{H}$ NMR $\delta 0.59$ (s, 6H), 1.84-1.93 (m, 4H), $2.23(\mathrm{dt}, J=3.9,14.7 \mathrm{~Hz}, 4 \mathrm{H}), 2.67$ (s, 4H), 2.93 (ddd, $J=3.8,11.1,14.7 \mathrm{~Hz}, 4 \mathrm{H}), 7.23-7.33$ (m, $6 \mathrm{H}), 7.52-7.55(\mathrm{~m}, 4 \mathrm{H}) ;{ }^{13} \mathrm{C}$ NMR $\delta-6.3,20.7,23.3,24.7,36.6,127.3,128.7,134.9,137.8 ;{ }^{29} \mathrm{Si}$ NMR $\delta$ 9.6, -14.9; IR (KBr) 2907, 2361, 1427, 1404, 1269, 1250, 1232, 1165, 1105, 985, 910, 883, 843, 821, 82, 787, 771, $713 \mathrm{~cm}^{-1}$; MS/EI $\mathrm{m} / z$ (10 eV) $504\left(\mathrm{M}^{+}, 83\right), 430$ (100), 356 (24), 281 (33), 260 (62), 221 (20), 103 (24); HRMS (EI) Calcd for $\mathrm{C}_{24} \mathrm{H}_{32} \mathrm{~S}_{4} \mathrm{Si}_{2}\left(\mathrm{M}^{+}\right)$504.0898. Found 504.0925. Anal. Calcd for $\mathrm{C}_{24} \mathrm{H}_{32} \mathrm{~S}_{4} \mathrm{Si}_{2}$ : C, 57.09; H, 6.39; S, 25.40\%. Found: C, 56.80; H, 6.31; S, $17.49 \%$.

1,5,9,13-Tetrathio-7,15-disila-7,7,15-trimethyl-15-phenyltrispiro[5,1,5,3]hexadecane (8b). Colorless plates; mp 131-132 ${ }^{\circ} \mathrm{C}$ (hexane/dichloromethane); ${ }^{1} \mathrm{H}$ NMR $\delta 0.51(\mathrm{~s}, 3 \mathrm{H}), 0.65(\mathrm{~s}, 3 \mathrm{H})$, $0.66(\mathrm{~s}, 3 \mathrm{H}), 1.80-2.13(\mathrm{~m}, 4 \mathrm{H}), 2.01(\mathrm{~d}, J=15.6 \mathrm{~Hz}, 2 \mathrm{H}), 2.34-2.58(\mathrm{~m}, 4 \mathrm{H}), 2.51(\mathrm{~d}, J=15.3$ $\mathrm{Hz}, 2 \mathrm{H}), 3.00-3.25(\mathrm{~m}, 4 \mathrm{H}), 7.31-7.49(\mathrm{~m}, 3 \mathrm{H}), 7.53-7.67(\mathrm{~m}, 2 \mathrm{H}) ;{ }^{13} \mathrm{C}$ NMR $\delta$-7.2, -6.7, -1.4, $23.2,23.8,24.2,24.8,127.6,128.9,133.5,138.6 ;{ }^{29} \mathrm{Si}$ NMR $\delta-9.6,7.5$; IR (KBr) 2948, 2930, 1428, 144, 1271, 1254, 1178, 1165, 1107, 986, 909, 884, 822, 741, 698, 473, $419 \mathrm{~cm}^{-1}$; MS/EI m/z $442\left(\mathrm{M}^{+}, 1\right), 312$ (19), 311 (26), 310 (100), 253 (43), 227 (63), 165 (54), 149 (41), 145 (31), 135 (32), 133 (49), 100 (89), 75 (37); HRMS (EI) Calcd for $\mathrm{C}_{19} \mathrm{H}_{30} \mathrm{~S}_{4} \mathrm{Si}_{2}\left(\mathrm{M}^{+}\right)$442.0769. Found 
442.0790 .

\section{1,5,9,13-Tetrathio-7,15-disila-7,7,15,15-tetramethyltrispiro[5,1,5,3]hexadecane}

(8c). Colorless plates; mp $177-178{ }^{\circ} \mathrm{C}$ (hexane/dichloromethane); ${ }^{1} \mathrm{H}$ NMR $\delta 0.20(\mathrm{~s}, 3 \mathrm{H}), 0.51(\mathrm{~s}, 3 \mathrm{H})$, 1.79-2.16 (m, 4H), 1.97 (s, 4H), 2.49 (dt, $J=3.9,14.7 \mathrm{~Hz}, 4 \mathrm{H}), 3.17$ (ddd, $J=3.4,11.3,14.6 \mathrm{~Hz}$, $4 \mathrm{H}) ;{ }^{13} \mathrm{C}$ NMR $\delta-6.7,-0.1,23.3,24.7,25.0,37.3 ;{ }^{29} \mathrm{Si}$ NMR $\delta$-3.2, 7.9; IR (KBr) 2940, 2905, 1559, 1429, 1404, 1273, 1244, 1194, 888, 847, 820, $785 \mathrm{~cm}^{-1}$; MS/EI $m / z(30 \mathrm{eV}) 382\left(\mathrm{M}^{+}+2\right.$, 13), $381\left(\mathrm{M}^{+}+1,14\right), 380\left(\mathrm{M}^{+}, 47\right), 250$ (34), 249 (42), 247 (100), 233 (23), 192 (36), 183 (47), 152 (65); Anal. Calcd for $\mathrm{C}_{14} \mathrm{H}_{28} \mathrm{~S}_{4} \mathrm{Si}_{2}$ : C, 44.16; H, 7.41; S, 33.68\%. Found: C, 43.95; H, 7.36; S, $33.68 \%$.

1,5,9,13-Tetrathio-7,15-disila-7-methyl-7,15,15-triphenyltrispiro[5,1,5,3]hexadecane (8d). Colorless plates; mp $94{ }^{\circ} \mathrm{C}$ (hexane/dichloromethane); ${ }^{1} \mathrm{H}$ NMR $\delta 1.00$ (s, 3H), 1.59-1.98 (m, $4 \mathrm{H}), 2.05-2.36(\mathrm{~m}, 4 \mathrm{H}), 2.69-3.05(\mathrm{~m}, 4 \mathrm{H}), 2.84(\mathrm{~s}, 4 \mathrm{H}), 7.22-7.80(\mathrm{~m}, 13 \mathrm{H}), 7.90-8.08(\mathrm{~m}, 2 \mathrm{H})$; ${ }^{13} \mathrm{C}$ NMR $\delta$-6.8, 21.6, 23.4, 24.0, 24.3, 36.6, 127.2, 127.3, 127.4, 128.77, 128.84, 130.4, 130.5, $134.8,134.9,136.7,137.7,137.8 ;{ }^{29} \mathrm{Si}$ NMR $\delta$-15.0, -2.1; IR (KBr) 3067, 297, 1655, 1428, 1252 , 1184, 1105, 909, 785, 735, 696, 540, 517, $415 \mathrm{~cm}^{-1}$; MS/EI m/z $566\left(\mathrm{M}^{+}, 1\right), 436(14), 435$ (25), 434 (81), 351(36), 313 (21), 289 (100), 259 (30), 215 (53), 207 (50), 197 (34), 181 (46), 145 (30), 137 (45), 105 (57), 100 (72), 77 (36); HRMS (EI) Calcd for $\mathrm{C}_{29} \mathrm{H}_{34} \mathrm{~S}_{4} \mathrm{Si}_{2}\left(\mathrm{M}^{+}\right.$) 566.1082. Found: 566.1088 .

1,5,9,13-Tetrathio-7,15-disila-7,15-dimethyl-7,15-diphenyltrispiro[5,1,5,3]hexadecane (8e). Isolated as a $53: 47$ mixture of two diastereomers; ${ }^{1} \mathrm{H}$ NMR (a mixture of two diastereomers) $\delta$ $0.71(\mathrm{~s}, 6 \mathrm{H}), 0.88(\mathrm{~s}, 3 \mathrm{H}), 1.05(\mathrm{~s}, 3 \mathrm{H}), 1.74-2.03(\mathrm{~m}, 8 \mathrm{H}), 2.21(\mathrm{~d}, J=15.6 \mathrm{~Hz}, 2 \mathrm{H}), 2.27(\mathrm{~d}, J=$ $16.8 \mathrm{~Hz}, 2 \mathrm{H}), 2.46(\mathrm{~d}, J=15.3 \mathrm{~Hz}, 2 \mathrm{H}), 2.22-2.35(\mathrm{~m}, 4 \mathrm{H}), 2.36-2.56(\mathrm{~m}, 4 \mathrm{H}), 2.68(\mathrm{~d}, J=15.6$ $\mathrm{Hz}, 2 \mathrm{H}), 2.87$ (dt, $J=3.6,10.4,14.1 \mathrm{~Hz}, 2 \mathrm{H}), 2.96-3.21(\mathrm{~m}, 6 \mathrm{H}), 7.34-7.53$ (m, 12H), 7.58-7.70 $(\mathrm{m}, 4 \mathrm{H}), 7.83-7.91(\mathrm{~m}, 2 \mathrm{H}), 8.12-8.20(\mathrm{~m}, 2 \mathrm{H}) ;{ }^{13} \mathrm{C}$ NMR (a mixture of two diastereomers) $\delta-7.3$, $-6.9,-1.0,-0.3,23.5,23.7,24.1,24.2,24.4,24.5,24.6,37.08,37.11,127.3,127.5,127.7,127.8$, $129.0,129.1,130.4,130.6,131.2,133.6,136.2,136.8,138.7 ;{ }^{29} \mathrm{Si}$ NMR (a mixture of two diastereomers) $\delta-9.8,-9.4,-4.7,-3.8$; IR (a mixture of two diastereomers, KBr) 2905, 1592, $1575,1565,1428,1271,1252,1198,1107,990,911,833,793,756,735,698 \mathrm{~cm}^{-1}$; MS/EI m/z $504\left(\mathrm{M}^{+}, 1\right), 374$ (19), 373 (45), 372 (100), 315 (22), 289 (61), 227 (69), 197 (41), 145 (46), 104 (45), 100 (90), 86 (56), 84 (12); ); HRMS (EI) Calcd for $\mathrm{C}_{24} \mathrm{H}_{32} \mathrm{~S}_{4} \mathrm{Si}_{2}\left(\mathrm{M}^{+}\right)$504.0925. Found 504.0922 .

1,5,9,13-Tetrathio-7,15-disila-7,15,15-tetramethyl-7-phenyltrispiro[5,1,5,3]hexadecane (8f). Colorless plates; mp 153-155 ${ }^{\circ} \mathrm{C}$ (hexane/dichloromethane); ${ }^{1} \mathrm{H}$ NMR $\delta 0.30(\mathrm{~s}, 6 \mathrm{H}), 0.92(\mathrm{~s}, 3 \mathrm{H}$ ), 1.65-2.05 (m, 4H), $2.04(\mathrm{~d}, J=15.1 \mathrm{~Hz}, 2 \mathrm{H}), 2.21(\mathrm{~d}, J=15.0 \mathrm{~Hz}, 2 \mathrm{H}), 2.28-2.55(\mathrm{~m}, 4 \mathrm{H}), 3.06$ $(\mathrm{ddd}, J=3.0,10.7,13.3 \mathrm{~Hz}, 4 \mathrm{H}), 7.28(\mathrm{~m}, 3 \mathrm{H}), 7.84-8.00(\mathrm{~m}, 2 \mathrm{H}) ;{ }^{13} \mathrm{C} \mathrm{NMR} \delta-6.9,0.1,0.5$, 24.0, 24.1, 24.7, 25.5, 37.2, 127.4, 130.3, 131.3, 136.5; ${ }^{29} \mathrm{Si}$ NMR $\delta-3.9,-3.0$; IR (KBr) 2942, 2907, 1489, 1431, 1402, 1269, 1246, 1192, 1103, 986, 882, 845, 81, 741, 731, 696, 530, $505 \mathrm{~cm}^{-}$

1; MS/EI m/z (28 eV) $445\left(\mathrm{M}^{+}+2,9\right), 444\left(\mathrm{M}^{+}+1,7\right), 443\left(\mathrm{M}^{+}, 30\right), 310$ (100), 295 (25), 282 (6), 253 (9), 227 (26), 218 (16), 183 (11), 152 (25); HRMS (EI) Calcd for $\mathrm{C}_{19} \mathrm{H}_{30} \mathrm{~S}_{4} \mathrm{Si}_{2}\left(\mathrm{M}^{+}\right.$) 442.0769. Found 442.0748. 
1,5,9,13-Tetrathio-7-sila-7,7-dimethyltrispiro[5,1,5,2]pentadecane (10a). Colorless plates; mp $122-123{ }^{\circ} \mathrm{C}$ (hexane/dichloromethane); ${ }^{1} \mathrm{H}$ NMR $\delta 0.42(\mathrm{~s}, 6 \mathrm{H}), 1.90-2.22(\mathrm{~m}, 4 \mathrm{H}), 2.46-2.64(\mathrm{~m}$, 4H), 2.55 (s, 4H), 3.07 (ddd, $J=3.5,11.0,12.9 \mathrm{~Hz}, 4 \mathrm{H}) ;{ }^{13} \mathrm{C}$ NMR $\delta$-5.8, 25.7 (2C), 37.7, 39.3;

${ }^{29} \mathrm{Si}$ NMR $\delta$ 25.7; IR (KBr) 2938, 2919, 2903, 1443, 1422, 1250, 1211, 1201, 1011, 926, 909, 843, 791, 766, 716, $673 \mathrm{~cm}^{-1}$; MS/EI m/z $322\left(\mathrm{M}^{+}, 4\right), 190$ (69), 132 (100), 100 (52), 84 (52), 71 (35); Anal. Calcd for $\mathrm{C}_{12} \mathrm{H}_{22} \mathrm{~S}_{4} \mathrm{Si}$ : C, 44.67; H, 6.87; S, 39.75\%. Found: C, 44.51; H, 6.66; S, $39.76 \%$.

1,5,9,13-Tetrathio-7-sila-7,7-dimethyltrispiro[5,1,5,3]hexadecane (10b). Colorless plates; $\mathrm{mp}$ $195{ }^{\circ} \mathrm{C}$ (hexane/dichloromethane); ${ }^{1} \mathrm{H}$ NMR $\delta 0.36$ (s, 6H), 1.70-2.03 (m, 6H), 2.28-2.48 (m, 8H), 3.01 (ddd, $J=2.9,12.0,14.4 \mathrm{~Hz}, 4 \mathrm{H}) ;{ }^{13} \mathrm{C}$ NMR $\delta-7.8,22.4,23.1,24.9,36.4,36.9 ;{ }^{29} \mathrm{Si} \mathrm{NMR} \delta$ 5.2; IR (KBr) 2917, 2886, 1421, 1412, 1271, 1250, 1242, 1163, 1048, 972, 909, 838, 812, 747 , 710, 658, $505 \mathrm{~cm}^{-1}$; MS/EI m/z $336\left(\mathrm{M}^{+}, 8\right), 191$ (57), 172 (100), 145 (47), 139 (14), 117 (15), 115 (13), 98 (15), 97 (16), 91 (37), 75 (26); Anal. Calcd for $\mathrm{C}_{13} \mathrm{H}_{24} \mathrm{~S}_{4} \mathrm{Si}: \mathrm{C}, 46.38$; H, 7.19; S, 38.09\%. Found: C, 46.23; H, 6.94; S, 37.09\%.

1,5,9,13-Tetrathio-7-sila-15-methylene-7,7-dimethyltrispiro[5,1,5,3]hexadecane

(10c). Colorless plates; mp $195-196{ }^{\circ} \mathrm{C}$ (hexane/dichloromethane); ${ }^{1} \mathrm{H}$ NMR $\delta 0.42$ (s, 6H), 1.70-2.10 $(\mathrm{m}, 4 \mathrm{H}), 2.44(\mathrm{dt}, J=3.0,10.3 \mathrm{~Hz}, 4 \mathrm{H}), 2.95-3.16(\mathrm{~m}, 4 \mathrm{H}), 3.05(\mathrm{~s}, 4 \mathrm{H}), 4.96(\mathrm{~s}, 2 \mathrm{H}) ;{ }^{13} \mathrm{C}$ NMR $\delta$-7.5, 23.4, 24.7, 36.4, 44.7, 116.1, 141.7; ${ }^{29} \mathrm{Si}$ NMR $\delta$ 5.9; IR (KBr) 3061, 2930, 1646, 1450 , 1437, 1431, 1416, 1263, 1259, 1117, 1040, 904, 828, 787, 718, $662 \mathrm{~cm}^{-1}$; MS/EI m/z $348\left(\mathrm{M}^{+}\right.$, 33), 242 (49), 199 (37), 184 (100), 183 (48), 149 (64), 137 (61), 119 (81), 110 (52), 91 (63), 87 (63), 75 (47); Anal. Calcd for $\mathrm{C}_{14} \mathrm{H}_{24} \mathrm{~S}_{4} \mathrm{Si}: \mathrm{C}, 48.23$; H, 6.94; S, 36.78\%. Found: C, 47.96; H, $6.76 ; \mathrm{S}, 37.40 \%$.

1,5,9,13-Tetrathio-7-sila-15-cyclohexylidene-7,7-dimethyltrispiro[5,1,5,3]hexadecane (10d). Colorless plates; mp $171-173{ }^{\circ} \mathrm{C}$ (hexane/dichloromethane); ${ }^{1} \mathrm{H}$ NMR $\delta 0.43(\mathrm{~s}, 6 \mathrm{H}), 1.45-1.68$ $(\mathrm{m}, 6 \mathrm{H}), 1.78-2.05(\mathrm{~m}, 4 \mathrm{H}), 2.26-2.36(\mathrm{~m}, 4 \mathrm{H}), 2.49$ (ddd, $J=3.4,5.3,14.4 \mathrm{~Hz}, 4 \mathrm{H}), 2.95$ (ddd, $J=3.3,10.8,14.3 \mathrm{~Hz}, 4 \mathrm{H}), 3.4(\mathrm{~s}, 4 \mathrm{H}) ;{ }^{13} \mathrm{C}$ NMR $\delta-6.5,24.6,24.8,26.7,27.7,31.4,37.7,40.5$, 122.0, 139.7; ${ }^{29} \mathrm{Si}$ NMR $\delta$ 6.8; IR (KBr) 2982, 2940, 1464, 1420, 1428, 1001, 986, 916, 874, 843, 785, 743, 712, $620 \mathrm{~cm}^{-1}$; MS/EI m/z $416\left(\mathrm{M}^{+}, 16\right), 326$ (16), 310 (15), 252 (39), 239 (22), 225 (74), 191 (33), 149 (34), 119 (94), 91 (100); Anal. Calcd for $\mathrm{C}_{19} \mathrm{H}_{32} \mathrm{~S} 4 \mathrm{Si}$ : C, 54.75; H, 7.74; S, 30.77\%. Found: C, 54.64; H, 7.58; S, 30.34\%.

1,5,9,13-Tetrathio-7-sila-15-hydroxy-7,7-dimethyltrispiro[5,1,5,3]hexadecane

(10e). Colorless plates; mp 200-202 ${ }^{\circ} \mathrm{C}$ (hexane/dichloromethane); ${ }^{1} \mathrm{H}$ NMR $\delta 0.30$ (s, 3H), 0.46 (s, 3H), 1.74-2.06 (m, 4H), $2.13(\mathrm{dd}, J=10.4,13.5 \mathrm{~Hz}, 2 \mathrm{H}), 2.34-2.52(\mathrm{~m}, 4 \mathrm{H}), 2.51(\mathrm{~d}, J=5.7 \mathrm{~Hz}, 1 \mathrm{H})$, 2.95-3.24 (m, 6H), 4.15-4.32 (m, 1H); ${ }^{13} \mathrm{C}$ NMR $\delta$-8.1, -7.9, 23.3, 23.4, 24.7, 34.7, 44.4, 67.3;

${ }^{29} \mathrm{Si}$ NMR $\delta$ 5.1; IR (KBr) 3548, 2957, 2361, 1734, 1456, 1262, 1199, 1165, 1111, 918, 826, 812, 747, 662, $565 \mathrm{~cm}^{-1}$; MS/EI m/z $352\left(\mathrm{M}^{+}, 22\right), 277$ (11), 246 (30), 245 (22), 2007 (22), 188 (6), 171 (47), 145 (72), 139 (46), 119 (48), 91 (59), 75 (100); Anal. Calcd for $\mathrm{C}_{13} \mathrm{H}_{24} \mathrm{OSS}_{4} \mathrm{Si}$ : C, 44.28; H, 6.86; S, 36.36\%. Found: C, 44.08; H, 6.86; S, 36.19\%.

15,16-Benzo-1,5,9,13-tetrathio-7-sila-7,7-dimethyltrispiro[5,1,5,4]heptadecane (10f). Colorless plates; mp $191{ }^{\circ} \mathrm{C}$ (dec, hexane/dichloromethane); ${ }^{1} \mathrm{H}$ NMR $\delta$ 0.17(s, 6H), 1.84-2.19 
(m, 4H), $2.53(\mathrm{dt}, J=3.8,14.4 \mathrm{~Hz}, 4 \mathrm{H}), 3.24(\mathrm{dt}, J=2.7,13.3 \mathrm{~Hz}, 4 \mathrm{H}), 3.75(\mathrm{~s}, 4 \mathrm{H}), 7.24(\mathrm{~s}$, $4 \mathrm{H}) ;{ }^{13} \mathrm{C}$ NMR $\delta-6.5,23.9,24.6,38.6,42.9,127.1,130.8,137.5 ;{ }^{29} \mathrm{Si}$ NMR $\delta 9.5$; IR (KBr) 2926, 2901, 2361, 1630, 1491, 1451, 1420, 1256, 1248, 1013, 988, 909, 824, 808, 781, 743, $660 \mathrm{~cm}^{-1}$; MS/EI m/z 398 (M+1 10), 234 (33), 233 (27), 201 (26), 160 (100), 147 (32), 119 (68), 117 (24), 115 (20), 91 (18), 75 (32); Anal. Calcd for $\mathrm{C}_{18} \mathrm{H}_{26} \mathrm{~S}_{4} \mathrm{Si}$ : C, 54.22; H, 6.57; S, 32.16\%. Found: C, 54.17 ; H, 6.64; S, 32.63\%.

A typical procedure for desulfurization. Preparation of 1,1,3,3,5,5-Hexamethyl-1,3,5trisilacyclohexane (11, CAS No. 1627-99-2)

A mixture of 7e $(0.19 \mathrm{~g}, 0.50 \mathrm{mmol}), \operatorname{AIBN}(8 \mathrm{mg}, 0.05 \mathrm{mmol})$ and $\mathrm{Bu}_{3} \mathrm{SnH}(1.08 \mathrm{~mL}, 4.0$ $\mathrm{mmol}$ ) was heated at $120{ }^{\circ} \mathrm{C}$ for $3 \mathrm{~h}$. The resulting mixture was distilled to give 11 (58 mg, bp $140{ }^{\circ} \mathrm{C} / 100 \mathrm{mmHg}$ ) as colorless oil in $64 \%$ yield. ${ }^{1} \mathrm{H}$ NMR $\delta-0.31(\mathrm{~s}, 6 \mathrm{H}), 0.05(\mathrm{~s}, 18 \mathrm{H}) ;{ }^{13} \mathrm{C}$ NMR $\delta 2.7,2.9 ;{ }^{29}$ Si NMR $\delta$ 0.3; IR (neat) 2953, 293, 1670, 1649, 1620, 1466, 1364, 1250, 146, $932,855,814,737,683,596 \mathrm{~cm}^{-1}$.

1,1,3-Trimethyl-3-phenyl-1,3-disilacyclobutane (12, [CAS No. 7550-40-5]). Colorless oil; bp $209{ }^{\circ} \mathrm{C} ;{ }^{1} \mathrm{H}$ NMR $\delta$ 0.20-0.44 (m, 4H), 0.25 (s, 3H), 0.35 (s, 3H), 0.49 (s, 3H), 7.36-7.45 (m, 3H), 7.58-7.68 (m, 2H); ${ }^{13} \mathrm{C}$ NMR $\delta 1.4,2.3,2.8,127.8,128.9,133.2,140.3 ; \mathrm{MS} / \mathrm{EI} \mathrm{m} / z 206\left(\mathrm{M}^{+}, 26\right)$, 191 (100), 163 (15), 149 (10), 145 (12), 135 (10), 121 (14), 113 (9), 105 (15), 97 (15), 95 (15), 83 (18), 81 (18), 74 (42), 71 (23), 69 (31).

1,1,2,2,4,4-Hexamethyl-1,2,4-trisilacyclopentane (13, [CAS No. 58679-67-7]). Colorless oil; bp $187{ }^{\circ} \mathrm{C} ;{ }^{1} \mathrm{H}$ NMR $\delta-0.28(\mathrm{~s}, 4 \mathrm{H}), 0.05(\mathrm{~s}, 6 \mathrm{H}), 0.12(\mathrm{~s}, 12 \mathrm{H}) ;{ }^{13} \mathrm{C}$ NMR $\delta-1.3,1.8,2.9 ;{ }^{29} \mathrm{Si}$ NMR $\delta$-12.9, 9.5; IR (neat) 2953, 2896, 1248, 1005, 990, 851, 797, 718, $610 \mathrm{~cm}^{-1}$; MS/EI m/z $202\left(\mathrm{M}^{+}, 40\right), 187$ (100), 171 (8), 129 (25), 113 (26), 99 (12), 85 (13), 73 (34).

1,1-Dimethyl-4,4-diphenyl-1,4-disilacyclohexane (14). Colorless oil; ${ }^{1} \mathrm{H}$ NMR $\delta 0.05$ (s, 6H), 0.78-0.95 (m, 4H), 1.31-1.49 (m, 4H), 7.30-7.81 (m, 10H); ${ }^{13} \mathrm{C}$ NMR $\delta-3.5,6.2,9.0,127.9$, 129.1, 134.4, 136.6; ${ }^{29} \mathrm{Si} \mathrm{NMR} \delta$-9.9, -0.2; IR (neat) 3069, 2899, 1970, 1880, 1825, 1428, 1246, 1115, 159, 824, 764, 725, $700 \mathrm{~cm}^{-1}$; MS/EI m/z $296\left(\mathrm{M}^{+}, 53\right), 281$ (27), 268 (49), 267 (88), 253 (23), 240 (98), 238 (36), 225 (100), 218 (78), 197 (39), 190 (84), 135 (58), 121 (62), 105 (73); Anal. Calcd for $\mathrm{C}_{18} \mathrm{H}_{24} \mathrm{Si}_{2}$ : C, 72.90; H, 8.16\%. Found: C, 72.79; H, 8.33\%.

1,1,4-Trimethyl-4-phenyl-1,4-disilacyclohexane (15). Colorless oil; ${ }^{1} \mathrm{H}$ NMR $\delta 0.00$ (s, 3H), $0.03(\mathrm{~s}, 3 \mathrm{H}), 0.22(\mathrm{~s}, 3 \mathrm{H}), 0.70-1.16(\mathrm{~m}, 8 \mathrm{H}), 7.32-7.42(\mathrm{~m}, 3 \mathrm{H}), 7.50-7.58(\mathrm{~m}, 2 \mathrm{H}) ;{ }^{13} \mathrm{C}$ NMR $\delta-$ $4.4,-3.9,-3.1,7.6,9.0,127.7,128.8,133.6,138.8 ;{ }^{29} \mathrm{Si}$ NMR $\delta$-5.4, -0.1; IR (neat) 3069, 2953, 2897, 1948, 1892, 1877, 1428, 1414, 1248, 1113, 1059, 980, 843, 787, 749, 691, $648 \mathrm{~cm}^{-1}$; MS/EI m/z 234 (M+, 29), 219 (38), 205 (53), 206 (55), 191 (38), 178 (100), 163 (73), 156 (39), 135 (61), 121 (80), 105 (61), 97 (24), 73 (20); HRMS (EI) Calcd for $\mathrm{C}_{13} \mathrm{H}_{22} \mathrm{Si}_{2}\left(\mathrm{M}^{+}\right) 234.1260$. Found 234.1242.

\section{Acknowledgements}

The present work was partially supported by Grants-in-Aid for Scientific Research (No. 
07405042), COE Research on Element Science, 21st century COE program for a united approach for new materials science, and Creative Scientific Research, No. 16GS0209 from Ministry of Education, Culture, Sports, Science and Technology and a Grant-in-Aid for "Research for the Future" Program (96R11601) from The Japan Society of the Promotion of Science. We are grateful to Prof. K. Tanaka, Prof. M. Haga, Dr. K. Tsuge, and Dr. K. Harada of the Institute for Molecular Science for X-ray diffraction analysis. We also thank Shin-Etsu Chemical Co. Ltd. for the generous gifts of organosilicon compounds.

\section{References}

1. (a) Birot, M.; Pillot, J.-P.; Dunogues, J. Chem. Rev. 1995, 95, 1443. (b) Interrante, L. V.; Liu, Q.; Rushkin, I.; Shen, Q. J. Organomet. Chem. 1996, 521, 1.

2. (a) Kinsho, T.; Shimizu, T.; Ogihara, T.; Kaneko, T.; Nakashima, M. 1995, EP 682,031; Chem. Abstr. 1996, 124, 161201k. (b) Kinsho, T.; Shimizu, T.; T. Ogihara, R. S.; Asakura, K.; Nakashima, M. 1995, EP 673,942; Chem. Abstr. 1996, 124, 72665x. (c) Ogihara, T.; Shimizu, T.; Kinsho, T.; Kaneko, T.; Saito, R.; Kurihara, H. 1995, EP 650,969; Chem. Abstr. 1995, 123, 270895q.

3. Brondani, D.; Carré, F. H.; Corriu, R. J. P.; Moreau, J. J. E.; Man, M. W. C. Angew. Chem. Int. Ed. 1996, 35, 324.

4. 1,1,4,4-Tetrafluoro-1,4-disilacyclohexane was reportedly utilized in the study of fluoride ion donor-acceptor system. (a) Hoshi, T.; Takahashi, M.; Kira, M. Chem. Lett. 1996, 683. 1,4Disilacyclohexanes with no substituent on the ring carbons were often obtained as minor products $(\sim 30 \%)$ in the polymerization of diorganovinylsilane via hydrosilylation. (b) Curry, J. W. J. Am. Chem. Soc. 1956, 78, 1686. (c) Curry, J. W. J. Org. Chem. 1961, 26, 1308. (d) Boury, B.; Corriu, R. J. P.; Leclercq, D.; Mutin, P. H.; Planeix, J.-M.; Vioux, A. Organometallics 1991, 10, 1457. (e) Fry, B. E.; Neckers, D. C. Macromolecules 1996, 29 , 5306.

5. Reviews on the synthesis of polysilacycloalkanes: (a) Barton, T. J. In Comprehensive Organometallic Chemistry. The Synthesis, Reactions and Structures of Organometallic Compounds; Ed.; Wilkinson, G.; Stone, F. G. A.; Abel, E. W., Ed.; Pergamon Press: Oxford, 1982; Vol. 2; pp 205-303; (b) Fritz, G. Angew. Chem. Int. Ed. 1987, 26, 1111; (c) Aylett, B. J.; Sullivan, A. C. In Comprehensive Organometallic Chemistry II; Abel, E. W.; Stone, F. G. A.; Wilkinson, G., Ed.; Pergamon Press: Oxford, 1995; Vol. 2; pp 45-75. See also, (d) Rousseau, G.; Blanco, L., Tetrahedron 2006, 62, 7951.

6. This dianionic methodology was often applied to the synthesis of carbocycles. For example, see Molander, G. A.; Shubert, D. C. J. Am. Chem. Soc. 1987, 109, 6877.

7. (a) Seyferth, D.; Rochow, E. G. J. Am. Chem. Soc. 1955, 77, 907. (b) Seyferth, D.; Attridge, C. J. J. Organomet. Chem. 1970, 21, 103; (c) Sakurai, H.; Umino, H. J. Organomet. Chem. 1977, 142, C49-C51. (d) Strohmann, C.; Lüdtke, S.; Wack, E. Chem. Ber. 1996, 129, 799. 
(e) Strohmann, C.; Lüdtke, S. In Organosilicon Chemistry II. From Molecules to Materials; Auner, N.; Weis, J., Ed.; VCH: Weinheim, 1996; pp 499-504.

8. Akkerman, O. S.; Bickelhaupt, F. J. Organomet. Chem. 1988, 338, 159.

9. (a) Mizuno, K.; Inamasu, N.; Shimizu, M.; Hiyama, T. Chem. Lett. 1996, 1083. (b) Shimizu, M.; Mizuno, K.; Inamasu, N.; Masai, H.; Hiyama, T. Inorg. Chim. Acta 1999, 296, 231.

10. Bis(methylthio)(trimethylsilyl)methyllithium was reported to undergo 1,4 -addition to cyclic enones in good yields. Seebach, D.; Bürstinghaus, R. Angew. Chem. Int. Ed. 1975, 14, 57.

11. Reviews of sulfur stabilization: (a) Stoyanovich, F. M. In Chemistry of Organosufur Compounds; Belen'kii, L. I., Ed.; Ellis Horwood: New York, 1990; pp 98-140. (b) Ogura, K. In Comprehensive Organic Synthesis; Trost, B. M.; Fleming, I., Ed.; Pergamon Press: Oxford, 1991; Vol. 1; pp 505-539.

12. (a) Block, E.; Aslam, M. Tetrahedron 1988, 44, 281. (b) Caubére, P.; Coutrot, P. In Comprehensive Organic Synthesis; Trost, B. M.; Fleming, I., Ed.; Pergamon Press: Oxford, 1991; Vol. 8; pp 835-870.

13. Preliminary reports: (a) Shimizu, M.; Iwakubo, M.; Nishihara, Y.; Hiyama, T. Tetrahedron Lett. 1998, 39, 3193. (b) Shimizu, M.; Iwakubo, M.; Nishihara, Y.; Hiyama, T. Tetrahedron Lett. 1998, 39, 3197.

14. (a) Fleming, I. In Comprehensive Organic Chemistry, Barton, D. H. R.; Ollis, W. D., Ed.; Pergamon Press: Oxford, 1979; Vol. 3; pp 541-686. (b) Bassindale, A. R.; Taylor, P. G. In The Chemistry of Organic Silicon Compounds; Patai, S.; Rappoport, Z., Ed.; John Wiley \& Sons, Inc.: New York, 1989; Vol. 2; pp 893-963. Also see, Shimizu, M.; Hata, T.; Hiyama, T. Tetrahedron Lett. 1997, 38, 4591.

15. For examples, see (a) Brook, A. G.; Duff, J. M.; Jones, P. F.; Davis, N. R. J. Am. Chem. Soc. 1967, 89, 431. (b) Corey, E. J.; Seebach, D.; Freedman, R. J. Am. Chem. Soc. 1967, 89, 434. (c) Salzmann, T. N.; Ratcliffe, R. W.; Christensen, B. G.; Bouffard, F. A. J. Am. Chem. Soc. 1980, 102, 6161. (d) Chuang, T.-H.; Fang, J.-M.; Jiaang, W.-T.; Tsai, Y.-M. J. Org. Chem. 1996, 61, 1794.

16. The generation of 1,3-dianion $\mathbf{1 b}$ in THF was confirmed by quenching with $\mathrm{D}_{2} \mathrm{O}$ to obtain the deutrated $\mathbf{5 b}$ in $81 \%$ yield $(98 \% d)$.

17. Wakefield, B. J. Organolithium Methods; Academic Press: London, 1988; Chapter 2, pp 2-3.

18. Crystals of 8a suitable for X-ray structure determination were obtained as colorless prisms by recrystallization from dichloromethane/hexane $(1: 1)$. Crystal data for 8a: C24H32Si2S4, $M=504.93$, triclinic, space group P1 (\#2), $a=10.505(2), b=14.898(2), c=10.077(2) \AA, \alpha$ $=102.35(1), \beta=116.88(1), \gamma=69.65(1)^{\circ}, V=1315.9(5) \AA^{3}, Z=2, \rho C a l c d=1.274 \mathrm{~g} \mathrm{~cm}^{-3}$, $F(000)=536.00,2 \theta \max =55.0^{\circ}, \operatorname{MoK} \alpha(\lambda=0.71069 \AA), \mu(\operatorname{MoK} \alpha)=4.62 \mathrm{~cm}^{-1}, T=296 \mathrm{~K}$; Of the 6363 reflections which were collected, 6032 were unique (Rint $=0.012$ ). The structure was solved by heavy-atom Patterson methods and expanded using Fourier techniques. The non-hydrogen atoms were refined anisotropically. Hydrogen atoms were included but not refined. The final cycle of full-matrix least-squares refinement was based on 4272 observed reflections $\{\mathrm{I}>3.00 \sigma(\mathrm{I})\}$ and 271 variable parameters and converged with 
unweighted and weighted agreement factors of $R=0.038$ and $R w=0.034$. All calculations were performed using the teXsan crystallographic software package of Molecular Structure Corporation. Crystallographic data have been deposited with Cambridge Crystallographic Data Centre as supplementary publication no. CCDC-100558.

19. Emsley, J. The Elements; Oxford University Press: Oxford, 2000.

20. Herman, A.; Wojnowski, W. Structural Chemistry 1992, 3, 239.

21. Bondi, A. J. Phys. Chem. 1964, 68, 441.

22. $\beta$-Donor interaction between silicon and nitrogen atoms in the solid state of dichlorobis(dimethylaminoxy)silane was reported. (a) Mitzel, N. W., Losehand, U. Angew. Chem. Int. Ed. Engl. 1997, 36, 2807. (b) Mitzel, N. W., Losehand, U. Eur. J. Inorg. Chem. 1998, 2023. See also, (c) Mitzel, N. W. Chem. Eur. J. 1998, 4, 692. 